\title{
Emerging nanomaterials for cancer immunotherapy
}

\author{
Sureshbabu Ram Kumar Pandian®, Clayton Fernando Rencilin, Krishnan Sundar*(1) \\ Department of Biotechnology, School of Bio and Chemical Engineering, Kalasalingam Academy of Research and Education, \\ Krishnankoil 626126, Tamil Nadu, India
}

*Correspondence: Krishnan Sundar, Department of Biotechnology School of Bio and Chemical Engineering Kalasalingam Academy of Research and Education Krishnankoil 626126, Tamil Nadu, India. sundarkr@klu.ac.in

Academic Editor: Haijun Yu, Shanghai Institute of Materia Medica, Chinese Academy of Sciences, China

Received: December 31, 2020 Accepted: April 23, 2021 Published: June 30, 2021

Cite this article: Ram Kumar Pandian S, Rencilin CF, Sundar K. Emerging nanomaterials for cancer immunotherapy. Explor Med. 2021;2:208-31. https://doi.org/10.37349/emed.2021.00043

\begin{abstract}
Immunotherapy is a unique approach to treat cancer that targets tumours besides triggering the immune cells. It attempts to harness the supremacy and specificity of immune cells for the regression of malignancy. The key strategy of immunotherapy is that it boosts the natural defence and manipulates the immune system at both cellular and molecular levels. Long-lasting anti-tumour response, reduced metastasis, and recurrence can be achieved with immunotherapy than conventional treatments. For example, targeting cytotoxic T-lymphocyte antigen-4 (CTLA4) by monoclonal antibody is reported as an effective strategy against cancer progression in vivo and chimeric antigen receptor (CAR) modified T-cells are known to express a stronger anti-tumour activity. CTLA4 and CAR are, therefore, beneficial in cancer immunotherapy; however, in clinical settings, both are expensive and cause adverse side effects. Nanomaterials have augmented advantages in cancer immunotherapy, besides their utility in effective delivery and diagnostics. In particular, materials based on lipids, polymers, and metals have been sought-after for delivery technologies. Moreover, the surface of nanomaterials can be engineered using ligands, antigens, and antibodies to target immune cells. In this sense, checkpoint inhibitors, cytokines, agonistic antibodies, surface receptors, and engineered T-cells are promising to regulate the immune system against tumours. Therefore, emerging nanomaterials that can be used for the treatment of cancer is the prime focus of this review. The correlation of mode of administration and biodistribution of various nanomaterials is reviewed here. Besides, the acute and chronic side effects and outcome of clinical trials in the context of cancer immunotherapy are discussed.
\end{abstract}

\section{Keywords}

Nanomaterials, cancer, immunotherapy, receptors, antigen

\section{Introduction}

Surgery, chemotherapy, radiation therapy, and immunotherapy are potential therapeutic approaches used for the treatment of various malignant and metastatic cancers. Despite adverse side effects and pain, surgery and chemotherapy are the primary treatment modalities for cancer. However, patients at late stages of cancer or 
post-surgery cancer recurrence remain hard to cure [1]. Immunotherapy selectively targets and eliminates cancer cells primarily by boosting the immune system. It eventually helps to ameliorate tumours, reduces metastasis, and tumour recurrence compared to other treatments [2]. Immunotherapy either suppresses or activates the immune system clinically under diseased conditions since both immunosuppression and immune evasion are strategies adopted by the cancer cells for growth and metastasis [2].

Tumours become metastatic by invading the adjacent healthy tissues. Ultimately, malignant tumours spread to various tissues/organs of the body. Unlike healthy cells, cancer cells express or over-express abnormal proteins, i.e. tumour-associated antigens (TAAs), due to their genetic instability [3-5]. Adoptive chimeric antigen receptor T-cell (CAR-T) based therapy is under clinical trial for recurring cancers and various metastatic cancers such as haematological malignancies [6], metastatic neuroblastoma [6, 7], glioblastoma [8], and prostate cancer [9]. Recently, the US Food and Drug Administration (FDA) has approved CD19-targeting CAR-T-cells for clinical use [10]. However, solid tumours possess complex mechanisms, which hamper the infiltration of immune cells that, in turn, promote immune suppression in the tumour microenvironment (TME). It eventually limits the anti-tumour efficacy of CAR-T and CAR-natural killer (NK) cells against solid tumours. Hence, approaches involving a combination of chemotherapy, radiotherapy, and immune checkpoint inhibitors are recommended, which will enhance the efficacy of CAR-T and CAR-NK cells against solid tumours [11].

The strategy of targeting TAA includes the administration of whole protein antigen [12], mature peptide epitopes [13], cell lysate [14], and adoptive transfer schemes [15]. CTL4 is a receptor protein expressed on the surface of $\mathrm{T}$ regulatory cells that downregulates the immune response [16]. Therefore, a monoclonal antibody (ipilimumab) has been developed and approved for cancer therapy [17]. Similarly, monoclonal antibodies, which target various receptors and ligands [e.g., programmed death protein-1 (PD-1)/programmed death-ligand 1 (PD-L1)], were approved for melanoma [18], non-small cell lung cancer (NSCLC) [19], head and neck squamous cell cancer (HNSCC), urothelial cancer, classical Hodgkin's lymphoma, and renal cell cancer [20]. Immunotherapy patients showed prolonged control over cancer than other treatments [21-23]. The immunological pathway activation could be in two ways: systemic or local. The first one utilizes systemic cytokine administration, whereas the latter employs immune checkpoint- or small molecule-inhibitors to manipulate the TME [24, 25].

The use of organic and inorganic nanomaterials refined the efficacy of cancer immunotherapy (Figure 1). Specifically, 1-200 nm size particles possess unique physiochemical properties. The potency of nanomaterials in cancer diagnosis and therapy has been demonstrated by many research groups [26-28]. Surface-modified nanomaterials selectively target and invade tumour tissues. The molecules with low bio-availability and biocompatibility reside in the inner core of surface-modified nanomaterials, thereby exhibit extended blood retention time, and reduced renal clearance. All these ideal characteristics are beneficial to treat widely distributed tumours with minimal toxicity [29-31]. Nanomaterials efficiently deliver molecules such as peptide [32], antigen [33], antibody [34], and whole-cell membrane [35]. These molecules often selectively inhibit or block various checkpoints [36] on immune cells and improve the efficacy of cancer immunotherapy. This review elucidates the starring role of nanomaterials and their augmentation in cancer immunotherapy. Besides, the physical characteristics of the immune system and cancer microenvironment are discussed. These characteristics are proven to interact with the biodistribution of nanocarriers. In the end, a few successful and on-going clinical trials of immunotherapy are summarized.

\section{Conventional cancer immunotherapy}

Immunotherapy has been developed as an alternative strategy against cancer during the past decade. Immunotherapy serves to prevent metastasis and to improve the quality of life of affected individuals. Immunotherapy can stimulate or inhibit various components of the immune system. These components include lymphokines, vaccines, effector cells, and antibodies [37]. The concept of immune surveillance is based on the early demolition of abnormal cells by the immune system, which prevents the development of tumour cells [37]. Therefore, lack of immune surveillance critically contributes to the development of the 
tumour. It may be accompanied by evasion of tumour cells from the immune surveillance system and an escape from T-cell-specific immunity [38, 39].

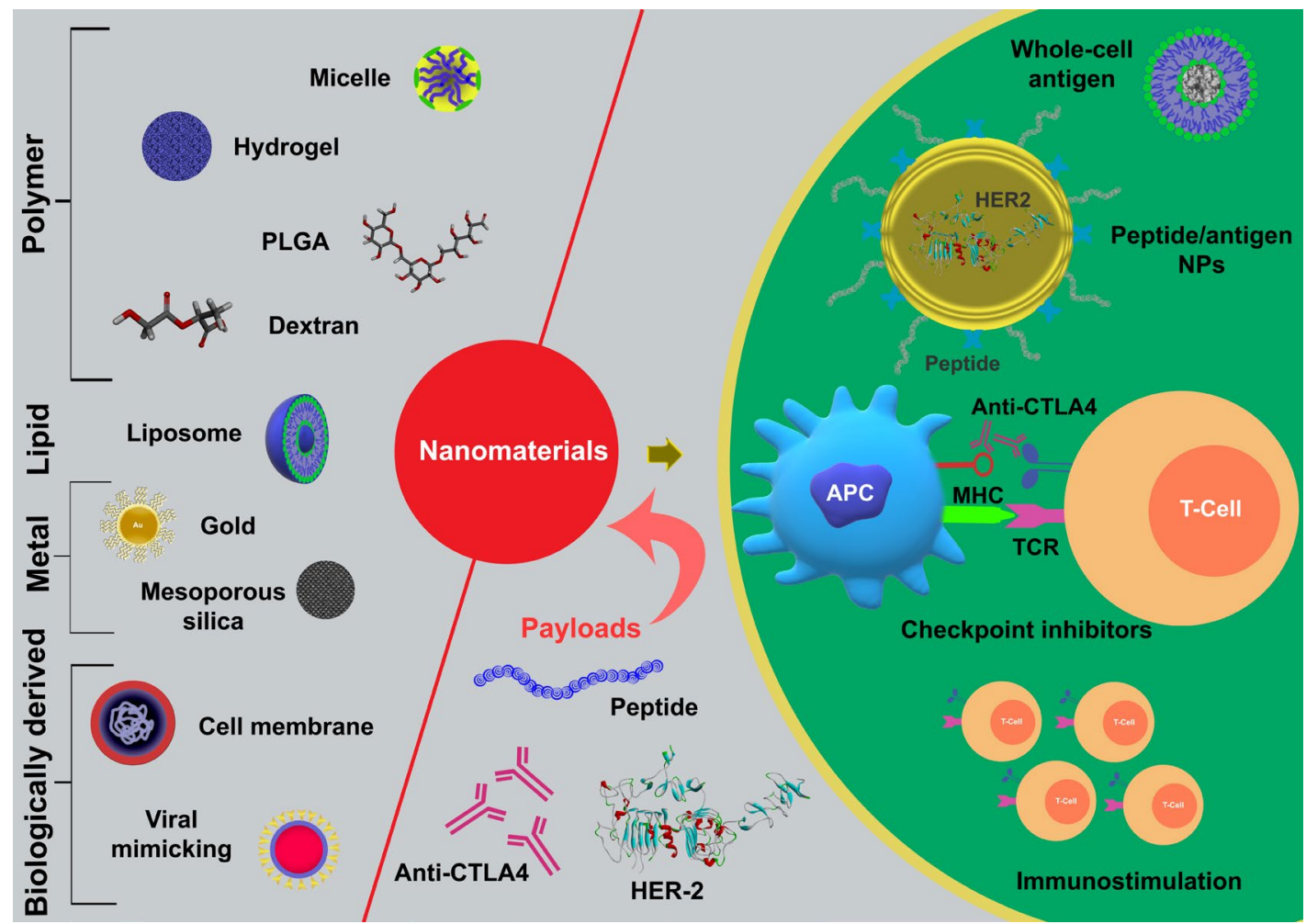

Figure 1. Overview of incipient nanomaterials and their role in cancer immunotherapy. Overview of incipient nanomaterials and their role in cancer immunotherapy. Nanoparticles derived from metal ions, biodegradable polymers, lipids, and cell membranes have been demonstrated to implicate in cancer immunotherapy. Nanomaterials are utilized as carriers to activate or suppress the immune system. Peptides, antigens, and antibodies are loaded into the inner core or surface of nanomaterials. In the RES, the modified nanoparticles showed enhanced bioavailability and prolonged stability. Besides, the particles escape from the damages caused by serum enzymes and other factors. When the payload is released into circulation, the particles systematically act on the immune cells. In advance, the whole-cell membrane camouflaged nanocarriers mimicking cancer cell prototypes by embracing identical antigens and receptors, by which APCs and killer cells can act. Nanomaterials, which possesses mAb (anti-CTLA4 or anti-PD-L1), can target immune checkpoint inhibitors and remodel TME in support of tumour-targeting immune cells. PLGA: poly (D, L-lactide-co-glycolic acid); NPs: nanoparticles; HER2: human epidermal growth factor receptor 2; APC: antigen-presenting cells; TCR: T-cell receptor

The use of CAR-T cells against the progression of many solid tumours such as colorectal cancer (CRC) has been evident by various reports. For instance, the anti-fluorescein-5-isothiocyanate (FITC)-labelled CAR-T cells were used to treat epidermal growth factor receptor (EGFR)-positive CRC. Besides, FITC-labelled cetuximab was used to treat EGFR-positive CRC [40]. Engineered cytokine-induced killer (CIK) cells with CAR targeting carcinoembryonic antigen (CEA) was developed from blood lymphocytes from CRC patients. The CAR-modified CIK cells proved for their specific selectivity in targeting autologous CRC [41]. In addition, four clinical trials were carried out by different research groups targeting HER2 [42], tumor-associated glycoprotein (TAG)-72 [43], CEA [44], or carcinoembryonic antigen-related cell adhesion molecule 5 (CEACAM5) [45] by CAR-T cells.

EpCAM (CD326), a $40 \mathrm{kDa}$ transmembrane glycoprotein, was overexpressed in many solid tumours and less-expressed in normal epithelial cells [46]. Therefore, EpCAM coupled second-generation CAR was developed and transduced into NK-92 cells by lentiviral vectors. The cytotoxicity and immunological effect of CAR-NK-92 cells were tested against colon cancer in vitro [47]. In another study, CAR-NK-92 cells were combined with regorafenib and used against EpCAM-positive tumour xenografts. The combination therapy was more effective than individual treatment (regorafenib or CAR-NK-92 cells) [47].

Even though CAR T-cell therapy showed remarkable clinical efficiency against solid tumours, the toxicity and the complexity of production make it a less-preferred approach in clinical settings. In general, CAR-T cells are prepared based on individual patient samples that imply the complexity of the process and expensive 
nature [48-50]. Therefore, an effective allogenic product is warranted to overcome these limitations. One such potential model is modified CAR-NK cells [10]. The dose-dependent safety and efficacy of CAR-NK cells were evaluated against CD19 positive cancer cells in clinical trials (phases 1 and 2). In a total of 11 patients, eight patients treated with CAR-NK cells have shown positive responses. Moreover, seven of them [4 with lymphoma and 3 with chronic lymphocytic leukemia (CLL)] showed complete remission. All these changes were noticed within 30 days of infusion but with different doses. Crucially, the administration of CAR-NK cells did not provoke adverse conditions (cytokine release syndrome, neurotoxicity, etc.) [10].

Modified CAR-T or CAR-NK extend new opportunities for cancer treatment [47]. NK cells contribute to cancer immune surveillance [51] through their inherent cytotoxicity and stimulation of cell surface receptors. Besides, NK cells adapt T-cell mediated anticancer immune responses by secreting cytokines and chemokines that trigger inflammatory responses [52]. Various scientific studies recognized the role of NK cells in cancer immune surveillance. NK cell-based adaptive immunotherapy is one of the rapidly developing fields. Efforts are in progress in refining the strategies to alternate CAR-engineered effector cells with NK cells [53, 54]. Furthermore, the transplantation of NK cells to a human leukocyte antigen (HLA)-mismatched recipient is considered reliable [55].

NK cells can activate both innate and adaptive immune systems to defend against both infections and cancer. NK cells are highly preferred in cancer immunotherapy [56] because of the following reasons: NK cells destroy cancer cells without antigen-specific stimulation [57]; NK cells secrete various cytokines [e.g., tumor necrosis factor-alpha (TNF- $\alpha$ )] to regulate the immune response [58]; NK cells aid in the maturation of APCs, which further activate $T$ cells to destroy tumour cells [59]. NK cells with the help of their membrane proteins [e.g., receptor activator of nuclear factor (NF)-kB-ligand (RANKL) or DNAX accessory molecule-1 (DNAM-1)], induce the polarization of M1-macrophage and target tumour cells [60-62]. NK cells directly activate antitumour immunity by eradicating the malignant cells; besides, NK cells exert tumour-specific adaptive immune response through crosstalk with dendritic cells [63]. NK cells control dendritic cells (DCs) maturation, which mediates T-cell activation [64]. Despite, DCs support the direct anti-tumour activity of NK cells [65]. However, owing to the immunosuppressive activity of the tumour, the function of NK cells in cancer patients is attenuated, which is, discouraging. Peripheral blood- and cord blood-derived NK cells from donors are used in lymphocyte infusions and to generate less-expensive genetically modified NK cells $[66,67]$. Heterogeneously expressed CAR-target antigens of NK cells attack tumours. Besides, the inherent cytotoxic property of NK cells can act as a counterpart to CAR-mediated destructive effects on cancer cells [63]. Taken together, the identification and blocking of immune checkpoints of NK cells and their tumour-specific redirection can be beneficial for both malignant and solid tumour patients. Given the advantages, these approaches are used in the development of therapeutics (CAR-T-cells- and CAR-NK-cells-based) for malignant glioma. In a preclinical mice model, transduced NK cells with anti-CD19 CAR, interleukin-15, and inducible caspase 9 showed improved anti-tumour activity compared to non-transduced NK cells (control) [67].

\section{Emerging organic and inorganic nanomaterials for immunotherapy}

Nanomaterial-based cancer immunotherapy poses more advantages than chemo- and immune-therapies. Due to their unique characters such as variable size, shape, charge, elasticity, and capability as an excipient, nanomaterials are highly preferred $[68,69]$. Specifically, the surface engineered-nanomaterials are useful in cancer immunotherapy to target specific receptors and transport peptides, antigens, adjuvants, antibodies, and small molecules [70]. Pharmacokinetics and pharmacodynamics studies revealed the enhancement stability, bioavailability, circulation, half-life time, and therapeutic efficacy of a drug or molecule when combined with a nanocarrier. Cancer immunotherapy utilizes both organic and inorganic nanomaterials. However, organic nanomaterials are preferred carrier molecules over inorganic nanomaterials due to their biocompatibility.

The capacity of liposomes to function as carriers for the delivery of drugs and vaccines has been investigated. Positively, the amphiphilic nature of liposomes effectively entraps both hydrophobic and hydrophilic molecules [71]. Besides, liposomes (positively-charged) exhibited immunostimulatory properties via activation of pro-inflammatory and pro-apoptotic pathways [72]. The activated pathways thus lead 
to the generation of reactive oxygen species (ROS) [73], the elevation of the expression of co-stimulatory molecules [74], and secretion of chemokines and cytokines. Polyethyleme glycol (PEG) coating to large liposomes ( $>100 \mathrm{~nm}$ ) facilitates the effective uptake by the lymph node (LN) [75]. A recent study reported the formulation of $\alpha$-galactosylceramide ( $\alpha$-GalCer; an adjuvant) and tyrosine-related protein 2 (TRP2) antigenloaded cationic liposomes prevented the tumour progression through cytotoxic T-cell response (CD8 ${ }^{+}$). $\alpha$-GalCer is a potent activator of NK-, and T-cells, as well as TRP2 is a melanocyte lineage-antigen expressed by malignant melanoma cells. Intravenous adjuvant and antigen delivery were successful using liposomes, which resulted in enhanced secretion of interferon-gamma (IFN- $\gamma$ ), activation of cytotoxic T-cells, and reduction of tumour survival. In addition, PEG-coating reduced the cytotoxicity of cationic liposomes at intravenous delivery [33]. The delivery of antigens using cationic liposomes in the intravenous system also facilitates the accumulation in the spleen and phagocytosis by CD8 ${ }^{+}$DCs $[76,77]$.

Plasma membrane vesicle (PMV) derived from a live source (cultivated cells, isolated tissues, etc.) function as a tumour-antigen delivery system. The plasma membrane-derived vesicles also contain lipid bilayers, which make them amenable for surface modification and to carry antigens. For instance, PMVs derived from breast cancer cells have delivered glycosylphosphatidylinositol (GPI)-HER-2 antigens and triggered both cellular and humoral immunity. It eventually resulted in delayed tumour growth and partial regression of established tumours [78]. In cancer cells, GPI-B7-1 or GPI-IL-12 induced T-cell proliferation. Besides, PMVs displaying GPI-B7-1 provoked tumour-specific T-cell-mediated cytotoxicity and protection [79].

Viral mimicking protein-based nanomaterials elicited the immune response under the TME. Also, non-viral pyruvate dehydrogenase E2 protein-nanoparticles exhibited biomimetic properties in cancer vaccine delivery. In melanoma glycoprotein 100 (gp100)-epitope, and cytosine-phosphate-guanine (CpG)oligonucleotide conjugation to E2 nanoparticles resulted in the antigen-specific cytotoxic-T-cell proliferation and IFN- $\gamma$ secretion by 1.5 -fold and 5 -fold, respectively [80]. Gardasil is the first clinically approved viruslike nanoparticle-based vaccine; besides, many other protein-based nanoparticulate assemblies have been suggested as vaccines that boost T-cell responses against various infectious diseases [81].

Microbubbles are used for the delivery of tumour antigen to DCs by the sonoporation method. The efficacy of antigen mRNA and TriMix mRNA inducing immune response have been evaluated in vivo. The codelivery of these mRNA modulated the function of DCs, and T cell phenotype [82]. Besides, the delivery of TriMix with TAA antigens leads to the induction of durable anti-tumour responses [83].

Mannose receptor targeting, ovalbumin-based dextran (DEX) nanoparticles have been reported for the induction of ovalbumin (OVA) peptide-specific $\mathrm{CD} 4^{+}$and $\mathrm{CD} 8^{+} \mathrm{T}$-cell proliferation both in vitro and in vivo. This OVA-DEX-based nano vaccine triggered humoral immune response [immunoglobulin G (IgG)1 > IgG2a], delayed-type hypersensitivity responses, and cytotoxic CD8 ${ }^{+} \mathrm{T}$ cells in vivo [84]. Acetylated DEX (Ac-DEX) nanoparticles with acetal-protecting groups were reported as immunotherapeutic agents. These agents possess the potential to elicit both major histocompatibility complex (MHC) I and MHC II presentation. Broaders et al. [85] loaded OVA antigen to Ac-DEX nanoparticles to enhance MHC presentation. Surprisingly, in the Ac-DEX nanoparticles-treated cells, the presentation of both MHC class I and II molecules ware observed.

Apart from organic materials, inorganic nanomaterials also demonstrated their potential for cancer immunotherapy. Gold nanoparticles were synthesized using melanoma B16F10 cells (AuNP@B16F10) and characterized. The particle size was $30 \mathrm{~nm}$, and the membrane thickness was between 4 and $6 \mathrm{~nm}$. In order to promote the antigen-presenting capability and to improve biocompatibility, DC-derived gold nanoparticles were synthesized (AuNP@DCB16F10) using the same cells. This complex (AuNP@DCB16F10) was capable of promoting the maturation of DCs, cytokine secretion, and T cell activation. Altogether, this study revealed the development of anti-tumour immunity and prevention of tumour metastasis and relapse [86].

Iron- and zinc-oxide based multifunctional core-shell nanoparticles deliver the CEA into DCs. The rapid uptake of nanoparticles by DCs was evidenced by confocal microscopy in vitro and magnetic resonance imaging in vivo. The antigen (CEA specific cellular immunity was demonstrated in nanoparticle complex-immunized C57BL/6 mice, in that a significant reduction in tumour growth was witnessed, compared to control. Besides, tumour-bearing mice showed delayed tumour growth and sustained survival, together evidenced the efficacy 
of antigen delivery by nanoparticle complex [87]. A recent report demonstrated the activation to DCs by mesoporous silica. The doping of silica with gold nanoparticles (Au@XL-MSNs) aided in the delivering of a high amount of CpG-oligodeoxynucleotides (ODNs) to the tumour site. Moreover, Au@XL-MSNs were effectively internalized in bone-marrow-derived dendritic cells (BMDCs) that increased the expression of co-stimulatory molecules and pro-inflammatory cytokines compared to soluble CpG-ODNs [88]. In this sense, we have summarized the list of fabricated nanomaterials used in cancer immunotherapy (Table 1).

Table 1. List of nanomaterials and their role in cancer immunotherapy

\begin{tabular}{|c|c|c|c|c|c|c|}
\hline $\begin{array}{l}\text { S. } \\
\text { No }\end{array}$ & $\begin{array}{l}\text { Type of } \\
\text { nano- } \\
\text { material }\end{array}$ & $\begin{array}{l}\text { Type of Nano- } \\
\text { materials }\end{array}$ & $\begin{array}{l}\text { Peptide/Antigen/ } \\
\text { Antibody/ }\end{array}$ & Cancer target & Functions & Ref. \\
\hline 1. & $\begin{array}{l}\text { Organic } \\
\text { Nano- } \\
\text { materials }\end{array}$ & PEI & LA-PegPI, pDNA & $\begin{array}{l}\text { Orthotopic hepatocellular } \\
\text { carcinoma mouse model }\end{array}$ & $\begin{array}{l}\text { Activation of CD8 }{ }^{+} \mathrm{T} \text { cells and NK } \\
\text { cells; upregulation of cytokines } \\
\text { (IFN- } \gamma, \mathrm{TNF} \text { and IL-12) }\end{array}$ & [153] \\
\hline 2. & & PPS & ss-TG & $\begin{array}{l}\text { B16-F10 melanoma, } \\
\text { E.G7-OVA thymoma } \\
\text { model }\end{array}$ & $\begin{array}{l}\text { OVA specific CD8 }{ }^{+} T \text { cells } \\
\text { and depletes Mo-MDSCs and } \\
\text { G-MDSCs }\end{array}$ & [154] \\
\hline 3. & & PEI & HA, ATRA & $\begin{array}{l}\text { HCT- } 8 \text { and CT- } 26 \text { tumor } \\
\text { models }\end{array}$ & $\begin{array}{l}\text { Necrotic cell death (MCP-1, } \\
\text { TNF- } \alpha \text { ) and antitumoral immune } \\
\text { responses }\end{array}$ & [155] \\
\hline 4. & & PEO-b-PCCL & $\begin{array}{l}\text { JSI-124 (cucurbitacin } \\
\text { I) }\end{array}$ & B16-F10 tumor & $\begin{array}{l}\text { Efficient delivery of STAT inhibitor; } \\
\text { Th1 immune responses (IL-2 and } \\
\text { IFN-y); suppress IL-6 responsible } \\
\text { for immature DC }\end{array}$ & [156] \\
\hline 5. & & nano-aAPC & $\begin{array}{l}\text { MACS microbeads, } \\
\text { MHC-Ig dimer and } \\
\text { anti-CD28 antibody, } \\
\text { TRP2 peptide }\end{array}$ & B16 melanoma & $\begin{array}{l}\text { Two-fold binding of TLR on } \\
\text { activated T cells; enhanced } \\
\text { antigen specific T-cells }\end{array}$ & [157] \\
\hline 6. & & PLGA & $\begin{array}{l}\text { ICG, R837 } \\
\text { (imiquimod) }\end{array}$ & $\begin{array}{l}\text { Breast cancer (fLuc- } 4 T 1 \text { ) } \\
\text { and colorectal cancer } \\
\text { (CT26) in female BALB/c } \\
\text { mouse }\end{array}$ & $\begin{array}{l}\text { Laser triggered tumour } \\
\text { associated antigens and anti- } \\
\text { CTLA4 checkpoint-blockade } \\
\text { therapy inhibits Tregs }\end{array}$ & [128] \\
\hline 7. & & $\begin{array}{l}\text { Chlorin-based } \\
\text { nanoscale } \\
\text { metal-organic } \\
\text { framework }\end{array}$ & IDO inhibitor & $\begin{array}{l}\text { CT26 and MC38 } \\
\text { colorectal cancer models } \\
\text { in BALB/c mice and } \\
\text { C57BL/6 mice and } \\
\text { murine melanoma cells } \\
\text { B16F10 }\end{array}$ & $\begin{array}{l}\text { T-cell infiltration, cell death, } \\
\text { antigen-specific IFN-y producing } \\
\text { T cells; eradicates primary and } \\
\text { treated tumours; diminished } \\
\text { MHC-II expression }\end{array}$ & [158] \\
\hline 8. & & $\begin{array}{l}\text { PEG-PLL-PLLeu } \\
\text { (PMP) }\end{array}$ & $\begin{array}{l}\text { PIC (TLR3 agonist), } \\
\text { OVA, STAT3 siRNA }\end{array}$ & $\begin{array}{l}\text { B16 melanoma cells as } \\
\text { TADC }\end{array}$ & $\begin{array}{l}\text { Elevated levels of CD86, CD } 40 \text {, } \\
\text { IL- } 12 \text { by tumour associated DC; } \\
\text { TADC activation, maturation and } \\
\text { decline of immunosuppression }\end{array}$ & [159] \\
\hline 9. & & Ac-DEX & OVA & $\begin{array}{l}\mathrm{B} 3 Z\left(\mathrm{CD} 8^{+}\right) \text {and } \mathrm{KZO} \\
\left(\mathrm{CD} 4^{+}\right) \text {cells in } \mathrm{C} 57 \mathrm{BL} / 6, \\
\mathrm{TAP}^{-1-} \text { and } \mathrm{B} 6 \mathrm{CBAF} 1\end{array}$ & $\begin{array}{l}\text { Superior MHC I presentation than } \\
\text { PLGA or iron oxide; presentation } \\
\text { by TAP dependent or independent } \\
\text { pathway }\end{array}$ & [85] \\
\hline 10. & & Dex & OVA, LPS & BMDCs & $\begin{array}{l}\text { T-cell mediated delayed type } \\
\text { hypersensitivity, cytotoxic T cell } \\
\text { induction in higher proportion, } \\
\text { CD4 }{ }^{+} \text {T cell proliferation }\end{array}$ & [84] \\
\hline 11. & & $\begin{array}{l}\text { Cholesterol/ } \\
\text { DOPC/ } \\
\text { maleimide- } \\
\text { PEGDSPE/ } \\
\text { PEG-DSPE } \\
\text { (PEGylated } \\
\text { liposomes) }\end{array}$ & Anti-CD40, CpG & $\begin{array}{l}\text { B16F10 murine model of } \\
\text { melanoma in C57BL/6 } \\
\text { mice }\end{array}$ & $\begin{array}{l}\text { Inhibition of tumour growth, } \\
\text { reduced side effects, high level of } \\
\text { distribution and presentation }\end{array}$ & [160] \\
\hline 12. & & $\begin{array}{l}\text { DOTAP cationic } \\
\text { liposome }\end{array}$ & PIC (TLR3 agonist) & $\begin{array}{l}\text { Hepa1-6 cell in C57BL/6 } \\
\text { mice }\end{array}$ & $\begin{array}{l}\text { Tumour specific CTL response, } \\
\text { NK cells, IFN- } \gamma \text {, type I IFN and } \\
\text { elevated maturation of mouse } \\
\text { BMDCs, IRF-3/IRF-7 mRNA } \\
\text { transcription }\end{array}$ & [161] \\
\hline 13. & & $\begin{array}{l}\text { Cationic } \\
\text { liposomes }\end{array}$ & $\begin{array}{l}\text { OVA peptide, TRP2 } \\
\text { peptide }\end{array}$ & $\begin{array}{l}\text { B16.F10luc2 or B16. } \\
\text { OVA melanoma cells into } \\
\text { C57Bl/6 mice }\end{array}$ & $\begin{array}{l}\text { Elevated level of IFN- } \gamma, \text { CTL } \\
\text { responses }\end{array}$ & [33] \\
\hline
\end{tabular}


Table 1. List of nanomaterials and their role in cancer immunotherapy (continued)

\begin{tabular}{|c|c|c|c|c|c|c|}
\hline $\begin{array}{l}\text { S. } \\
\text { No }\end{array}$ & $\begin{array}{l}\text { Type of } \\
\text { nano- } \\
\text { material }\end{array}$ & $\begin{array}{l}\text { Type of Nano- } \\
\text { materials }\end{array}$ & $\begin{array}{l}\text { Peptide/Antigen/ } \\
\text { Antibody/ }\end{array}$ & Cancer target & Functions & Ref. \\
\hline 14. & & $\begin{array}{l}\text { Lipid micro- } \\
\text { bubbles }\end{array}$ & mRNA lipoplexes & $\begin{array}{l}\text { Melanoma cell line MO4 } \\
\text { and T cell lymphoma } \\
\text { E.G7-OVA in C57BL/6 } \\
\text { and OT-I mice }\end{array}$ & $\begin{array}{l}\text { Antigen specific T-cell lysis the } \\
\text { APC, long term immunological } \\
\text { memory }\end{array}$ & {$[82]$} \\
\hline 15. & & $\begin{array}{l}\text { PMV from } \\
\text { murine } \\
\text { melanoma (B16- } \\
\text { OVA) }\end{array}$ & $\begin{array}{l}\text { Lipid [3(nitrilo- } \\
\text { triacetic acid)- } \\
\text { ditetradecylamine], } \\
\text { CD11c, DEC-205, } \\
\text { OVA, Adjuvant } \\
\text { (IFN-y, LPS, GM- } \\
\text { CSF) }\end{array}$ & $\begin{array}{l}\text { Metastatic murine } \\
\text { B16-OVA melanoma in } \\
\text { C57BL/6 mice }\end{array}$ & $\begin{array}{l}\text { Targets DC and induces CTL } \\
\text { responses-depends on DC } \\
\text { maturation, IFN- } \gamma \text {, LPS, eotaxin. }\end{array}$ & [162] \\
\hline 16. & & PMV & $\begin{array}{l}\text { GPI, HER-2, IL-12, } \\
\text { B7-1 }\end{array}$ & $\begin{array}{l}\mathrm{D} 2 \mathrm{~F} 2 / \mathrm{E} 2 \text { cells in BALB/c } \\
\text { mice }\end{array}$ & $\begin{array}{l}\text { Specific hummoral (lgG) and } \\
\text { cellular (Th1 and Th2) immunity }\end{array}$ & [78] \\
\hline 17. & & HNSCC, PDTC & GNP, cisplatin (Pt) & $\begin{array}{l}\text { Homotypic tumor cells } \\
\text { from patient-derived } \\
\text { xenograft model }\end{array}$ & $\begin{array}{l}\text { Enhanced targeting, almost } \\
\text { complete eradication of tumour }\end{array}$ & [106] \\
\hline 18. & & aAPC & CD80, OVA & $\begin{array}{l}\text { Murine melanoma cell } \\
\text { line in C57BL/6 mice }\end{array}$ & $\begin{array}{l}\text { Stimulated antigen presentation, } \\
\text { T-cell responses without the need } \\
\text { of professional APC }\end{array}$ & [35] \\
\hline 19. & & $\begin{array}{l}\text { Pyruvate } \\
\text { dehydrogenase } \\
\text { E2 protein }\end{array}$ & $\begin{array}{l}\text { CpG, melanoma } \\
\text { assoicated gp } 100 \\
\text { epitope }\end{array}$ & $\begin{array}{l}\text { B16-F10 murine } \\
\text { melanoma cell line } \\
\text { in C57BL/6 mice and } \\
\text { pmel-1 }\end{array}$ & $\begin{array}{l}1.5 \text { fold increase of CD8 }{ }^{+} \mathrm{T} \text { cells } \\
\text { and } 5 \text { fold increase of IFN- } \mathrm{Y} \\
\text { than unbound peptide and CpG; } \\
\text { increases survival time of } 40 \%\end{array}$ & [80] \\
\hline 20. & & PLL & GCpD, CpG-ODN & $\begin{array}{l}\text { EMT6 murine mammary } \\
\text { cancer model }\end{array}$ & $\begin{array}{l}\text { Photoimmunotherapy: pro- } \\
\text { inflammatory response and } \\
\text { maturation of dendritic cells; } \\
\text { imaging; targets TLR9 }\end{array}$ & [163] \\
\hline 21. & & Chitosan & HCuSNPs, CpG & $\begin{array}{l}\text { EMT6 tumor in BALB/c } \\
\text { mice }\end{array}$ & $\begin{array}{l}\text { Tumour cell death; effective } \\
\text { systemic immune responses } \\
\text { (CD8 } 8^{+} \text {T cells, IFN- } \gamma \text { and IL-2) }\end{array}$ & [164] \\
\hline 22. & $\begin{array}{l}\text { Inorganic } \\
\text { Nano- } \\
\text { materials }\end{array}$ & Gold & $\begin{array}{l}\text { PLGA- } b \text {-PEG, ZnPc, } \\
\text { CpG-ODN }\end{array}$ & $\begin{array}{l}\text { 4T1 metastatic mouse } \\
\text { breast carcinoma cells }\end{array}$ & $\begin{array}{l}\text { Immunoadjuvant and antitumour } \\
\text { response: Th17, NK, B-cell, NK, } \\
\text { IFN- } y \text {, etc. }\end{array}$ & [165] \\
\hline 23. & & $\begin{array}{l}\text { Iron oxide-zinc } \\
\text { oxide }\end{array}$ & $\begin{array}{l}\text { PEO-PPO-PEO, Zn } \\
\text { binding motifs }\end{array}$ & $\begin{array}{l}\text { CEA-expressing cancer } \\
\text { cells (MC38/CEA) in } \\
\text { C57BL/6 mice }\end{array}$ & $\begin{array}{l}\text { Tumour antigen specific T cells; } \\
\text { delayed tumour growth }\end{array}$ & [87] \\
\hline 24. & & Iron oxide & DMSA, IFN-y & $\begin{array}{l}\text { Murine Pan02 pancreatic } \\
\text { ductal adenocarcinoma } \\
\text { cell line in C57BL/6 mice }\end{array}$ & $\begin{array}{l}\text { Enhanced T cell, macrophage } \\
\text { infiltration and antiangiogenic } \\
\text { effect }\end{array}$ & [166] \\
\hline 25. & & CuS & LPS & $\begin{array}{l}\text { CT26 tumor in BALB/c } \\
\text { mice }\end{array}$ & $\begin{array}{l}\text { Treats and prevents CT26 tumor } \\
\text { in spleen and liver; activation } \\
\text { of dendritic cells and antigen } \\
\text { specific immune responses }\end{array}$ & [167] \\
\hline 26. & & PBNP & anti-CTLA-4 & $\begin{array}{l}\text { Neuroblastoma } \\
\text { (Neuro2a) cells in } \mathrm{A} / \mathrm{J} \\
\text { mice }\end{array}$ & $\begin{array}{l}\text { increased infiltration of } \\
\text { lymphocytes and T cells to the } \\
\text { tumor area with the help of anti- } \\
\text { CTLA4 }\end{array}$ & [168] \\
\hline 27. & & PEG & $\begin{array}{l}\text { GO, HPPH, HK } \\
\text { peptide }\end{array}$ & $\begin{array}{l}\text { Pulmonary metastatic } \\
4 \text { T1 cells (4T1-fLuc) in } \\
\text { BALB/c mice }\end{array}$ & $\begin{array}{l}\text { Activates dendritic cells, infiltrates } \\
\text { CD8 }{ }^{+} \mathrm{T} \text { cells; prevents tumour } \\
\text { growth and lung metastasis with } \\
\text { immunological memory }\end{array}$ & [169] \\
\hline 28. & & $\mathrm{ZnP}$ & Pyrolipid, anti-PD-L1 & $\begin{array}{l}\text { 4T1 breast tumor cells in } \\
\text { BALB/c mice }\end{array}$ & $\begin{array}{l}\text { Inducing apoptosis, necrosis, } \\
\text { disrupting tumor vasculature and } \\
\text { increasing tumor immunogenicity; } \\
\text { eliminates primary tumours and } \\
\text { induces CTC responses }\end{array}$ & [170] \\
\hline 29. & & AuNP & B16F10 cells, PTT & $\begin{array}{l}\text { Murine Melanoma } \\
\text { Model B16F10 cells and } \\
\text { breast cancer cells } 4 T 1 \\
\text { in Balb/c and C57BL/6 } \\
\text { mice }\end{array}$ & $\begin{array}{l}\text { Inhibition of tumour metastasis, } \\
\text { tumour relapse, eradication of } \\
\text { primary tumour, induces Dc } \\
\text { maturation, T cell activation, } \\
\text { cytokine secretion }\end{array}$ & [86] \\
\hline
\end{tabular}


Table 1. List of nanomaterials and their role in cancer immunotherapy (continued)

\begin{tabular}{|c|c|c|c|c|c|c|}
\hline $\begin{array}{l}\text { S. } \\
\text { No }\end{array}$ & $\begin{array}{l}\text { Type of } \\
\text { nano- } \\
\text { material }\end{array}$ & $\begin{array}{l}\text { Type of Nano- } \\
\text { materials }\end{array}$ & $\begin{array}{l}\text { Peptide/Antigen/ } \\
\text { Antibody/ }\end{array}$ & Cancer target & Functions & Ref. \\
\hline 30. & & $\begin{array}{l}\text { Mesoporous } \\
\text { silica and AuNP } \\
\text { (Au-XL-MSN) }\end{array}$ & CpG, PEG & $\begin{array}{l}\text { B16-F10 cells in C57/ } \\
\text { BL6 mouse }\end{array}$ & $\begin{array}{l}\text { Antigen specific adaptive } \\
\text { immunity, effective uptake of } \\
\text { bone marrow DC, activates TLR9, } \\
\text { synergestic therapeutic inhibits } \\
\text { strongly tumour, induced IL-12, } \\
\text { TNF- } \alpha\end{array}$ & {$[88]$} \\
\hline 31. & & MSNP & PEI, Curcumin & $\begin{array}{l}\text { Breast adenocarcinoma } \\
\text { (MCF-7) cells }\end{array}$ & $\begin{array}{l}\text { Efficient intracellular uptake, } \\
\text { non-toxic, disrupts mitochondria } \\
\text { and nucleus lead to induction of } \\
\text { apoptosis }\end{array}$ & [171] \\
\hline 32. & & $\begin{array}{l}\text { GPC3-targeting } \\
\text { CAR-T cell } \\
\text { membrane }\end{array}$ & IR780, MSNP & $\begin{array}{l}\text { Hepatocellular } \\
\text { carcinoma Huh-7 cells } \\
\text { and SK-HEP-1 in BALB/ } \\
\text { c-nu mice }\end{array}$ & $\begin{array}{l}\text { Enhanced targeting ability, } \\
\text { photothermal response and } \\
\text { reduced toxicity. }\end{array}$ & [172] \\
\hline 33. & & UCNPs & $\begin{array}{l}\text { PEG, Ce6, R837 } \\
\text { (imiquimod), anti- } \\
\text { CTLA4 }\end{array}$ & $\begin{array}{l}\text { CT26 murine colorectal } \\
\text { cancer cell line in } \\
\text { Female BALB/c mice }\end{array}$ & $\begin{array}{l}\text { Anti-tumour response with strong } \\
\text { memory; stimulate DC maturation } \\
\text { and pro-inflammatory cytokine } \\
\text { secretion (IL-12, IFN-y and } \\
\text { TNF- } \alpha \text { ), inhibits Tregs eliminate } \\
\text { primary tumours }\end{array}$ & [173] \\
\hline
\end{tabular}

Mo-MDSCs: monocytic myeloid-derived suppressor Cells; G-MDSCs: granulocytic-MDSCs; PEI: poly-ethylenimine; PPS: polypropylene-sulfide; ss-TG: ss-thromboglobulin; HA: hyaluronic acid; ATRA: all-trans-retinoic acid; MCP-1: monocyte chemotactic protein-1; PEO-b-PCCLL: poly(ethylene oxide)-block-poly( $\alpha$-carboxylate- $\varepsilon$-caprolactone); nano-aAPC: nanoscale artificial antigen presenting cells; MACS: magnetic-activated cell sorting; ICG: indocyanine green; IDO: indoleamine 2,3-dioxygenase; TADC: tumor-associated dendritic cell; LPS: lipopolysaccharide; DSPE: distearoylphosphoethanolamine; DOTAP: 1,2-dioleoyl3-trimethylammonium-propane; PIC: polyriboinosinic polyribocytidylic acid; CTL: cytotoxic T lymphocyte; IRF: interferon regulatory factor; GM-CSF: granulocyte-macrophage colony-stimulating factor; PDTC: patient-derived tumor cell; GNP: gelatin nanoparticle; GCpD: graphene quantum dots; CpG-ODN: CpG-oligodeoxynucleotides; PLL: poly-L-lysine; PEG-PLL-PLLeu: PEG- $b$-PLL- $b$-poly(L-leucine); PMP: polypeptide micelle/poly I:C; CuS: copper sulfide; HCuSNPs: hollow CuS nanoparticles; PEO-PPO-PEO: PEO- $b$-poly(propylene oxide)- $b$-PEO; DMSA: dimercaptosuccinic acid; PBNP: prussian blue nanoparticle; GO: graphene oxide; HPPH: photosensitizer; HK: histidine-lysine; ZnP: Zn-pyrophosphate; PTT: photothermal therapy; MSNP: mesoporous silica nanoparticle; Ce6: chlorin e6; UCNPs: upconversion nanoparticles; TAP: transporter associated with antigen processing

\section{Delivery of peptide and antigen by nanomaterials}

Effective and site-specific delivery of immune-modulating agents are key characteristics of a vaccine; therefore, these characteristics are considered in the nano-vaccine formulations [89]. It is reported that peptides and proteins in their soluble form induce low level of immune response due to the poor uptake by APC. Furthermore, peptides and proteins elicit non-specific interactions and susceptible to enzymatic degradations. Finally, the antigen presentation process is hampered, and uptake of antigen by immune cells is diverted [90]. Conversely, delivery of peptides and proteins with organic nanomaterials such as liposomes and polymeric carriers protect them from enzymatic degradation and enhance their uptake by APC [91]. Nanomaterials guard the encapsulated or immobilized materials (antigen/adjuvant) from the renal clearance and surrounding biological environment. Further, it enhances the half-life, reduces toxicity, endorses delivery to APCs, and sometimes, directly activates the TAA specific T-cells [92]. For instance, antigens and adjuvantsencapsulated nanomaterials enhanced the activation of T- and B-cell immune response compared to soluble antigens. The delivery of antigens to APCs by nanoparticles provoked an adaptive immune response, as evidenced in vivo. Kasturi et al. [93] revealed that a biodegradable synthetic, $300 \mathrm{~nm}$-sized polymer (PLGA) encapsulated with Toll-like receptor (TLR) ligands [monophosphoryl lipid A (MPLA); TLR4 ligand and R837; TLR7 ligand] and antigen used in immunization of mice, improved the antibody and T-cell responses compared to control (soluble antigen plus MPL and R837). The significance is that the delivery of antigen or peptide with nanoparticles resemble the immunogenicity of live viral vaccines [94].

The APCs (e.g., DC) play a crucial role in inducing adaptive immune response, which involves capturing, processing, and presentation of antigens [95]. DC vaccination implicates strong T-cell responses against both self and foreign antigens [32]. The delivery of peptides or proteins by nanoparticles enhanced the antigen uptake property of DCs and aided in the sustained release of antigens by nanocarriers that eventually facilitated both cellular and humoral responses [90]. In DCs, the uptake of soluble and particulate antigens is mediated 
by pinocytosis and phagocytosis, respectively. However, phagocytosis potentially induces a higher level of immune response compared to pinocytosis [96]. The effective uptake of apoptotic bodies, latex particles, liposomes by DCs was reported earlier [97]. PLGA nanoparticles loaded with a human MUC1 lipopeptide (2,765 Da- sized cancer-associated antigen [BLP25; ( $\varepsilon$-palmitoyl) G], and MPLA were delivered to murine bone marrow-derived DCs in vitro. Ultimately, the PLGA nanoparticles were phagocytised and enhanced the expression of MHC class II and CD 86 molecules compared to control [32]. PLGA nanoparticles were also delivered to cord blood-derived DCs [98]. Similarly, polystyrene-beads were delivered to monocyte-derived DCs [99].

Overexpression of HER-2 receptor tyrosine kinase has been observed in diverse human malignancies such as breast, ovarian, gastric, non-small cell lung, and salivary gland cancers. HER-2 is thus associated with the prognosis of malignant cells [100]. In this purview, peptide vaccination has induced T-cell responses (both $\mathrm{CD}^{+}$and $\mathrm{CD}^{+}$receptor-mediated) against HER-2 [101]. Further, a humanized HER2-specific monoclonal antibody named Hercpetin is clinically approved for HER2-targeted immunotherapy [102]. In

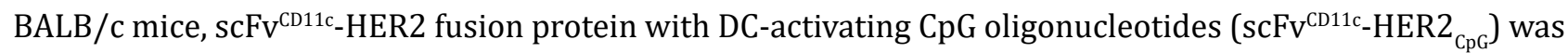
administered. Consequently, HER2-specific immune response was initiated, which hampered the growth of HER2-expressing tumour cells [103]. Plant virus [icosahedral cowpea mosaic virus (CPMV) and filamentous potato virus X (PVX)]-based nanoparticles were reported to deliver HER2 epitopes in cancer immunotherapy (HER2 ${ }^{+}$malignant cancer). Upon administration, CPMV and PVX nanoparticles were phagocytised by DCs, which lead to the accumulation of nanoparticles in draining LNs and stimulation of HER2-specific humoral response [104].

\section{Cell-membrane delivery by nanomaterials}

The delivery of various antigens (CEA and galectin-3) was evidenced in the cancer microenvironment [105]. The surface-coating of nanoparticles using cancer cell membrane resulted in biomimetic nanomaterials. These particles exhibit inherited homologous targeting potential [106]. The use of cell membranes for the functionalization of nanoparticles offers a novel approach and the unique advantage of holding a complete copy of antigenic structure and functions [107]. A series of cell membrane-camouflaged nanomaterials from source cells have been demonstrated for their inherited features. A few examples are as follow: nanoparticles coated with neutrophil cell membrane neutralize proinflammatory cytokines [108]; nanomaterials camouflaged with platelet membrane damaged the vasculature and pathogens [109]; leukocyte-membrane coated microspheres pose the ability to cross the endothelium [110]; and red blood cell (RBC) membraneencrusted particles exhibit extended circulation time [111]. Nanomaterials with membrane-bound tumour antigens signal the immune system to recognize and combat cancer [112]. Further, cancer cell membrane mimicking particulate vectors surface-functionalized with antigens have been fabricated to enhance vaccine potency $[113,114]$.

Cell membrane immunotherapy helps to stimulate the immune systems against tumours. For instance, NK cells elicit M1-macrophage polarization that induced the immune system. NK-cell membrane coated nanoparticles cloaked with photosensitizer 4,4',4",4"' -(porphine-5,10,15,20-tetrayl) tetrakis (benzoic acid) (TCPP)-loaded NPs were used to eliminate primary and metastatic tumours in vivo. The TCPP-coated nanoparticles induced cancer cell death via photodynamic therapy. [115].

PLGA nanoparticles are loaded with R837 (TLR7 agonist) and coated with membranes of B16-OVA cancer cells. Besides, the surface modification of the nanoparticles (NP-R@M-M) was achieved with the mannose adopting the lipid-anchoring method. The surface modification enhanced the internalization of the particles in DCs. Upon intradermal injection, these particles efficiently migrated into draining LNs and prompted tumour-specific immune responses. The developed NP-R@M-M nanoparticles demonstrated as a prophylactic vaccine to defend against cancer cells in mice. Also, these particles, in combination with antiPD-1 checkpoint inhibitors, exhibited as a therapeutic vaccine to combat melanoma progression [116].

B16-F10 mouse melanoma cell membranes have been used to camouflage PLGA nanoparticles. Cancer cell membrane nanoparticles (CCNPs) possess an antigenic exterior that closely resembles a source of 
cancer cells. CCNPs, along with TAA, immunological adjuvants, are effectively delivered to APCs to promote antitumour response [116]. Since the coated cell membrane consists of a cell adhesion molecule identical to the source cell, it reflects a homotypic binding mechanism that can be used for cell-specific targeting [105].

Recently a biomimetic nanoparticle platform has been reported to stimulate T-cells directly in the absence of APCs. Engineering aAPCs provide control over antigen presentation since the cells can replace endogenous counterparts [117]. Both living cells and cell line can be engineered to express suitable MHC and co-stimulatory markers on their surface. These engineered aAPCs have been demonstrated to engage and activate T cells. In recent times, developing particulate APCs have paid greater attention [118]. Especially, nano-scaled APCs hold many advantages. It enhances lymphatic transport when administrated subcutaneously [119]. The wildtype B16-F10 (B16-WT) murine melanoma cell line has been chosen to express two different antigens; OVA and CD80. The first is a model antigen, and the latter is a co-stimulatory marker, which engages CD28 receptor of T-cells. The membranes of engineered cancer cells were separated and cloaked on PLGA nanoparticles. The double knock-in nanoparticle formulation acquires endogenous signals for $\mathrm{T}$ cell stimulation and is demonstrated to control tumour growth in murine models [35].

\section{Delivery of checkpoint inhibitor by nanomaterials}

Checkpoint inhibitors are either made up of proteins or monoclonal antibodies. These inhibitors downregulate the immune system by CTLA-4 and PD-1 signalling pathways and support the cancer cells [120]. In this sense, anti-CTLA-4 and anti-PD-1/PD-L1 were proposed as checkpoint inhibitors of various malignancies such as Hodgkin's lymphoma [121], NSCLC [122], CRC [123], bladder cancer [124], and urinary tract cancer [125]. PD-1 is found on the cell surface of both activated T and B, whereas PD-L1 is a transmembrane protein [126]. The interaction led to an immunosuppressive environment, in which downregulation of $\mathrm{T}$ regulatory cells and inhibition of antigen-specific immune cells is crucial. These usual immune processes maintain the homeostasis of the immune system and to prevent autoimmunity complications. However, some metastatic tumours evade immune detection by altering the expression of PD-1/PD-L1 [127]. Therefore, inhibiting immunosuppression reaction by blocking the protein (PD-L1 or PD-1) is considered a potent strategy for downregulating tumour cell prognosis.

Neuropilin-1 (Nrp 1) is a key receptor of regulatory T (Treg) cells. Hybrid nanoparticles surface decorated with tLyp1 peptide has been reported to target Nrp1. The high-affinity binding of tLyp1 with Nrp 1 of Treg leads to the suppression of the function of Treg cells by tLyp1-hNPs. This anti-CTLA4-based immunecheckpoint blockade approach bolsters $\mathrm{T}$ cell response in the cancer microenvironment and potentiates tumour demolition [36].

Co-encapsulated PLGA nanoparticles (ICG, photothermal agent) and TLR-7 agonist imiquimod (R837); PLGA-PEG-ICG-R837] along with intravenous administration of anti-CTLA4 were used in the treatment of mammary carcinoma 4T1 (mice model). The fabricated nanoparticles exhibited vaccine-like properties against primary tumours by expressing tumour associated antigens. Also, intravenous administration of anti-CTLA4 has generated immunological responses that inhibit metastasis and prognosis of tumour. ICGbased photothermal therapy was used to abolish the tumours in vivo. Autopsy results of tumour-draining LNs revealed the infiltration of activated and matured DCs at the tumour site [128].

Nanoparticle mediated activation of LN resident DCs along with co-administration of anti-PD-L1 was often proved in long-term control of metastatic tumours. In brief, micellar-based, pathogen mimicking nanoparticles were loaded with TLR4-agonist and OVA model antigen against metastatic tumours. Bacteria (Xanthomonas campestris and E. coli)-derived cubic iron oxide nanoparticles possess lipooligosaccharides (TLR4-agonist) and suitable for in vivo trafficking and multimodal imaging. These particles induce M1 macrophage polarization, therefore used in DC-based vaccination. These nano-based vaccines exhibited enhanced protection against aggressive B16-F10 murine melanomas and abolition of PD-L1 expression melanomas, with $100 \%$ tumour rejection [129]. 


\section{Small molecules in cancer immunotherapy}

Small molecules targeting specific pathways or cells with a capability of immune modulation are anticipated to improve the efficacy in cancer immunotherapy. Small molecules are well characterized for their systemic administration and toxic effects. Hence, they are amenable for both extracellular and intracellular targets. These molecules can influence the molecular pathways that regulate immune tolerance and suppression towards effective antitumour response [130]. As mentioned earlier, the PD-1/PD-L1 axis inhibits TCR and CD28 signalling is a potential target for cancer immunotherapy; at present, antibodies are used to target the axis. However, small-molecules also may be used for targeting the PD-1/PD-L1 axis. Imiquimod, an imidazoquinoline derivative, commonly prescribed for genital warts is the first small-molecule drug approved by the FDA for the treatment of basal cell carcinoma [131]. The small-molecules such as BMS (BMS-103, $-142,-200,-202,-242,-1001$, and -1166), that act through a novel dimer-locking mechanism has shown promising results in vitro $[132,133]$. Arginase is another promising target in the TME. ARG I inhibitor CB1158 (INCB001158), inhibited the myeloid cell mediated immune suppression of T-cell proliferation in T-cell cocultures, that reducing tumour growth in different mouse models [76]. Compared to antibodies, smallmolecules can penetrate tissues easily; therefore, they can targeted both extracellular and intracellular to endorse antitumour immunity [130]. Small-molecules that studied for cancer immunotherapy and under clinical trials are reviewed in detailed by Zanden et al. [130]. Though, various small-molecules targeting the PD-1/PD-L1 axis are under focus, their development lagging behind the efficiency of monoclonal antibodys (mAbs) due to disputes in formulating molecules to occupy the hydrophobic PD-1/PD-L1 interface with high affinity [130].

\section{Challenges in biodistribution of nanoparticles}

Nanomaterials were employed in the diagnosis and used as drugs to target various diseases including, metastatic cancer. Nanomaterials are conjugated with drugs that have poor bioavailability. Besides, improved tissue selectivity, enhanced protection for payload, reduced renal clearance, and extended circulation period are considered as merits for nanomaterials. However, delivery of molecules such as peptides, proteins, antigens, antibodies, and nucleic acids, produce side effects. However, the characteristics of these molecules are different from pre- to post-encapsulation. In this sense, predicting the pharmacokinetics property and assessment of biodistribution efficiency is crucial. It helps to determine the efficacy and side effects of a given drug [134]. The pharmacokinetics of nanoparticles were accessed by accounting various chemical and physical properties (size, charge, surface chemistry, etc.).

When nanomaterials administered in vivo, a variety of serum proteins readily bind to the surface of nanoparticles that enhances the engulfment property of macrophage and results in significant loss of payload in the circulation [135]. The substance that binds to the nanoparticle is called opsonin, which, in turn, mediates the clearance of nanomaterials by macrophage through the reticuloendothelial system (RES). In this purview, reduction of protein binding is significant while developing nanoparticles with an extended circulation time [134]. The potential of nanoparticles and their biological applications is not only agreed by the physiochemical properties but also based on the interactions with the surrounding molecules. However, nanomaterials, in some circumstances, alter the function of the immune system and provoke significant health risks. Therefore, the safety of a nanoparticle (even for a non-toxic nanomaterial) is a potential human health concern [136]. Previous studies demonstrated that nanoparticles either induce or inhibit the innate immune response [137]. The innate immune system works at the nanoscale in that the size of nanoparticles resembles viruses. The immune system thus considers nanoparticles as foreign material (like viruses) and provokes the immune response in a systematic way [138]. Specifically, the interaction of immune cells with nanoparticles causes phase transformations, particle aggregation, surface reconstruction, and dissolution. These processes eventually affect the reactivity, bioavailability, and pharmacokinetic properties of the nanoparticles [139]. The altered characteristics may provoke immunotoxic effects. Therefore, a guided strategy is recommended to fabricate the multi-purpose nanoparticles. 


\section{Challenges in cancer immunotherapy}

Cancer immunotherapy is a sought-after method in the treatment of metastatic tumours. Yet, the challenges in the clinical progress of immunotherapy are to be addressed. The cancer-related characteristics vary in patients and are determined by the surrounding microenvironment [140]. Moreover, some tumours are arising followed by chronic inflammatory conditions, whereas other malignancies destabilize or co-opt immune responses as part of their progression [140]. Every single process, such as screening of drugs, determine the drug delivery and dose, schedule, and administration of drugs, and revealing the molecular mechanism, are pivotal in cancer therapy. The use of animal models has helped to appropriate immunotherapy (e.g., CTLA-4 and PD-L1/PD-1 blockade) [141, 142]. Despite various animal models of cancer, a great degree of disparity exist between the immunology of human cancer and animal models [143, 144]. For instance, the composition of APCs, T- and B-cells in the TME, presence of tumour antigens, and complexity of immune cell modulation or suppression differ between human cancers and animal models of cancer [145, 146]. The complications of cancer immunotherapy have been discussed in detail by Hegde and Chen [140]. Considering these challenges would help to improve pre-clinical models, clinical biomarkers, organ-specific immunity, and so on.

\section{Cancer immunotherapy and clinical trials}

Clinical trials are successful in screening successful anti-cancer drugs. In the past decade, CAR T-cell based clinical trials exhibited significant therapeutic potential and are, therefore, approved by US-FDA. The CAR T-cell based immunotherapy is a hallmark in cancer treatment. Immunotherapy is advantageous in many ways; it exhibited prolonged and comprehensive retardation in patients and demonstrated to have potential in manipulating the immune system against cancer $[147,148]$. The resilient success of the immunotherapeutic approach leads to several clinical against metastatic tumours. The trials investigated various treatment modalities (single or combination of drugs). In the context of cancer immunotherapy, we have summarized a list of drugs, their clinical trials, stages, and approval code in Table 2. For example, nivolumab (humanized $\mathrm{mAb}$ and PD-1 checkpoint inhibitor) and lpilimumab (fully human mAb and CTLA-4 checkpoint inhibitor) were primitively reported as immunotherapeutic agents against metastatic melanoma. It was a randomized, double-blind, and phase 3 study conducted with metastatic melanoma patients. The combination of nivolumab and ipilimumab were resulted in progression-free survival [34]. Albeit CAR T therapies are reportedly successful against haematological cancer, their impact on solid epithelial based cancers was not significant [149].

Metal nanoparticle-based, immune checkpoint-targeting, combinational therapy was popular against advanced cancer stages. In an open-label, phase I trial, NBTXR3 with radio- and anti-PD-1 therapies (NCT03589339), the anti-tumour response, safety, feasibility, and kinetic profile of the drug were considered as outcome measures within the expected time frame (24 months) [150].

A monoclonal antibody (nivolumab; an anti-PD-1 antibody, and ipilimumab; an anti-CTLA-4 antibody) was combined with a synthetic drug (anthracycline and cyclophosphamide) to determine the efficacy of combinational therapy in a phase IIb trial (ICON; NCT03409198). Anthracycline is considered immunogenic, and low-dose cyclophosphamide is used to counteract immunosuppressive cells. This study was approved in 2018 for immunogenic chemotherapy [151].

Sipuleucel-T was used to design a therapeutic cancer vaccine. The formulation consists of autologous peripheral-blood mononuclear cells (PBMCs) and APCs, both of which were activated with recombinant fusion protein (PA2024) ex vivo. PA2024 was a combination of prostate antigen and prostatic acid phosphatase; both were fused to granulocyte-macrophage colony-stimulating factor. In a double-blind, randomized, placebo-controlled, phase 3 trial, 512 patients were assigned to receive either Sipuleucel-T (341 patients) or placebo (171 patients; NCT00065442). Consequently, men with metastatic castration-resistant prostate cancer showed prolonged survival. However, adverse side effects (chills, fever, and headache) were reported in sipuleucel-T treated patients [152].

Polymeric nanoparticles loaded with Cetuximab and decorated with a somatostatin analogue. Cetuximab is a chimeric monoclonal antibody formulated against EGFR-targeting cancer cells. When administered orally, 
the polymeric nanoparticles released the loaded drugs using ethylcellulose polymer and are stable at above the $\mathrm{pH}$ 6.8. The nanoparticles protect the drug (Cetuximab) even at extreme acidic pH (1.5). In CRC cells, somatostatin receptor (SSTR) is overexpressed. Therefore, the formulated nanoparticles selectively target the cancer cells octreotide (an SSTR agonist). Besides, the pharmacokinetic parameters of Cetuximab were measured for 12 months (NCT03774680). Nanomedicine is thus a potential immunotherapeutic agent, as demonstrated by a plethora of experiments and clinical trials. Further, many conceptual and evidence-based approaches are under clinical trials, which become worthwhile soon.

Table 2. List of on-going nano based clinical trials for cancer immunotherapy

\begin{tabular}{|c|c|c|c|c|c|c|}
\hline $\begin{array}{l}\text { S. } \\
\text { No }\end{array}$ & Title of the study & $\begin{array}{l}\text { Nano- } \\
\text { particle } \\
\text { used }\end{array}$ & Target & Developer & $\begin{array}{l}\text { Clinical } \\
\text { stage }\end{array}$ & $\begin{array}{l}\text { Clinical trial } \\
\text { code/Ref }\end{array}$ \\
\hline 1 & $\begin{array}{l}\text { A randomized, double-blind, placebo } \\
\text { controlled phase III study to investigate } \\
\text { efficacy and safety of first-line } \\
\text { treatment with HLX10 + chemotherapy } \\
\text { (carboplatin-nanoparticle albumin bound } \\
\text { (nab) paclitaxel) in patients with stage } \\
\text { IIIB/IIIC or IV NSCLC }\end{array}$ & Albumin & $\begin{array}{l}\text { Squamous non- } \\
\text { small cell lung } \\
\text { lancer }\end{array}$ & $\begin{array}{l}\text { Shanghai Henlius } \\
\text { Biotech }\end{array}$ & Phase 3 & NCT04033354 \\
\hline 2 & $\begin{array}{l}\text { A study to evaluate safety/tolerability } \\
\text { of immunotherapy combinations in } \\
\text { participants with triple-negative breast } \\
\text { cancer or gynecologic malignancies }\end{array}$ & Albumin & $\begin{array}{l}\text { Breast cancer, } \\
\text { ovarian cancer }\end{array}$ & $\begin{array}{l}\text { Arcus Biosciences, } \\
\text { Inc., Infinity } \\
\text { Pharmaceuticals, } \\
\text { Inc. }\end{array}$ & Phase 1 & NCT03719326 \\
\hline 3 & $\begin{array}{l}\text { Bispecific antibody armed activated } \\
\text { T-cells with aldesleukin and } \\
\text { sargramostim in treating patients with } \\
\text { locally advanced or metastatic pancreatic } \\
\text { cancer }\end{array}$ & Albumin & $\begin{array}{l}\text { Metastatic } \\
\text { pancreatic } \\
\text { adenocarcinoma, } \\
\text { pancreatic } \\
\text { carcinoma }\end{array}$ & $\begin{array}{l}\text { Barbara Ann } \\
\text { Karmanos Cancer } \\
\text { Institute, National } \\
\text { Cancer Institute } \\
(\mathrm{NCl})\end{array}$ & $\begin{array}{l}\text { Phase } \\
1,2\end{array}$ & NCT02620865 \\
\hline 4 & $\begin{array}{l}\text { NBTXR3 activated by radiation therapy } \\
\text { for the treatment of locally advanced or } \\
\text { borderline-resectable pancreatic cancer }\end{array}$ & $\begin{array}{l}\text { Hafnium } \\
\text { oxide }\end{array}$ & $\begin{array}{l}\text { Borderline } \\
\text { resectable } \\
\text { pancreatic } \\
\text { adenocarcinoma, } \\
\text { locally advanced } \\
\text { pancreatic ductal } \\
\text { adenocarcinoma, } \\
\text { resectable } \\
\text { pancreatic ductal } \\
\text { adenocarcinoma }\end{array}$ & $\begin{array}{l}\text { M.D. Anderson } \\
\text { Cancer Center, } \\
\mathrm{NCl}\end{array}$ & Phase 1 & NCT04484909 \\
\hline 5 & $\begin{array}{l}\text { Investigating the effects of Mikei® red } \\
\text { reishi essence EX on the immune system } \\
\text { of prostate cancer patients and patients } \\
\text { with non-cancerous conditions of the } \\
\text { prostate }\end{array}$ & Gold & Prostate cancer & $\begin{array}{l}\text { Nikkei (Canada) } \\
\text { Marketing Limited }\end{array}$ & NA & NCT03589781 \\
\hline 6 & $\begin{array}{l}\text { IMX-110 in patients with advanced Solid } \\
\text { tumors }\end{array}$ & NA & $\begin{array}{l}\text { Solid tumor, } \\
\text { advanced solid } \\
\text { tumors, pancreatic } \\
\text { cancer, breast } \\
\text { cancer, ovarian } \\
\text { oancer }\end{array}$ & $\begin{array}{l}\text { Immix Biopharma } \\
\text { Australia Pty Ltd, } \\
\text { Immix Biopharma, } \\
\text { Inc. }\end{array}$ & $\begin{array}{l}\text { Phase } \\
1,2\end{array}$ & NCT03382340 \\
\hline
\end{tabular}

\section{Conclusions}

In this review, various insights are covered with respect to conventional cancer immunotherapy, nanomaterials under investigation (pre-clinical and phase trials), and the mode of action of different nanomaterials on immune system. Cancer immunotherapy, in part, solicits the immune system to manipulate the immunosurveillance. Various parameters in the TME may either render support or hamper the immunotherapy. The presence and absence of Treg cells, tumour associated macrophages, and expression of TAA are considered pivotal. Our viewpoint of previous studies proposes nanomaterials as a promising entity to enhance cancer immunotherapy. Specifically, biological nanomaterials reinforced the efficacy of immunotherapy because of their unique characteristics and functions. The nanoparticle can be used as an immune stimulator or adjuvant (to deliver or presenting peptide, specific antigen, or whole cell membrane). Put together, the 
nanoparticles are useful to target checkpoint inhibitors and to reverse the immunosuppressive condition of TME. The outcome of pre-clinical and clinical trials endowed the motivation for clinical testing of diverse concepts. The studies and examples conversed herein may shed light on novel possibilities and approaches against malignancies soon. However, persuading challenges (inadequate knowledge of patient and TME, lack of impersonating animal models) in cancer immunotherapy need to be overcome. These facts would expand the field of immune-oncology and facilitate the venturing of cancer immunotherapy into a new era.

\section{Abbreviations}

aAPC: artificial APCs

Ac-DEX: acetylated DEX

CAR: chimeric antigen receptor

CAR-T: chimeric antigen receptor T-cell

CEA: carcinoembryonic antigen

CpG: cytosine-phosphate-guanine

CRC: colorectal cancer

CTLA4: cytotoxic T-lymphocyte antigen-4

DCs: dendritic cells

DEX: dextran

EGFR: epidermal growth factor receptor

FDA: Food and Drug Administration

GPI: glycosylphosphatidylinositol

ICG: indocyanine green

LN: lymph node

mAbs: monoclonal antibodys

MHC: histocompatibility complex

NK: natural killer

NSCLC: non-small cell lung cancer

OVA: ovalbumin

PD-1: programmed death protein-1

PD-L1: programmed death-ligand 1

PEG: polyethyleme glycol

PLGA: poly $(D, L$-lactide-co-glycolic acid)

PMV: plasma membrane vesicle

TAAs: tumour-associated antigens

TLR: Toll-like receptor

TME: tumour microenvironment

Treg: regulatory $\mathrm{T}$

\section{Declarations}

\section{Author contributions}

SRKP designed the main theme of this review and involved in the development of a hypothesis. He collected the data and contributed to the writing of this review. CFR involved in the collection of data, development of the hypothesis, and drafting the tables. KS guided the design of this review and hypothesis. He edited the overall manuscript and authenticated the technical value of this manuscript. 


\section{Conflicts of interest}

The authors declare that they have no conflict of interest in the publication.

\section{Ethical approval}

Not applicable.

\section{Consent to participate}

Not applicable.

\section{Consent to publication}

Not applicable.

\section{Availability of data and materials}

Not applicable.

\section{Funding}

KS would like to acknowledge the financial support by Science and Engineering Research Board of India (EMR/2016/003035). CFR acknowledges Kalasalingam Academy of Research and Education for financial assistance in the form of Post-graduate Scholarship. The funders had no role in study design, data collection and analysis, decision to publish, or preparation of the manuscript.

\section{Copyright}

(C) The Author(s) 2021.

\section{References}

1. Hu T, Li Z, Gao CY, Cho CH. Mechanisms of drug resistance in colon cancer and its therapeutic strategies. World J Gastroenterol. 2016;22:6876-89.

2. Song W, Musetti SN, Huang L. Nanomaterials for cancer immunotherapy. Biomaterials. 2017;148:16-30.

3. Keogh E, Fikes J, Southwood S, Celis E, Chesnut R, Sette A. Identification of new epitopes from four different tumor-associated antigens: recognition of naturally processed epitopes correlates with HLAA*0201-binding affinity. J Immunol. 2001;167:787-96.

4. Kawakami Y, Eliyahu S, Delgado CH, Robbins PF, Sakaguchi K, Appella E, et al. Identification of a human melanoma antigen recognized by tumor-infiltrating lymphocytes associated with in vivo tumor rejection. Proc Natl Acad Sci U S A. 1994;91:6458-62.

5. Rosenberg SA. Cancer vaccines based on the identification of genes encoding cancer regression antigens. Immunol Today. 1997;18:175-82.

6. Pule MA, Savoldo B, Myers GD, Rossig C, Russell H V, Dotti G, et al. Virus-specific T cells engineered to coexpress tumor-specific receptors: persistence and antitumor activity in individuals with neuroblastoma. Nat Med. 2008;14:1264-70.

7. Louis CU, Savoldo B, Dotti G, Pule M, Yvon E, Myers GD, et al. Antitumor activity and long-term fate of chimeric antigen receptor-positive T cells in patients with neuroblastoma. Blood. 2011;118:6050-6.

8. Brown CE, Alizadeh D, Starr R, Weng L, Wagner JR, Naranjo A, et al. Regression of glioblastoma after chimeric antigen receptor T-cell therapy. N Engl J Med. 2016;375:2561-9.

9. Junghans RP, Ma Q, Rathore R, Gomes EM, Bais AJ, Lo ASY, et al. Phase I trial of anti-PSMA designer CAR-T cells in prostate cancer: possible role for interacting interleukin 2-T cell pharmacodynamics as a determinant of clinical response. Prostate. 2016;76:1257-70.

10. Liu E, Marin D, Banerjee P, Macapinlac HA, Thompson P, Basar R, et al. Use of CAR-transduced natural killer cells in CD19-positive lymphoid tumors. N Engl J Med. 2020;382:545-53. 
11. Xu J, Tian K, Zhang H, Li L, Liu H, Liu J, et al. Chimeric antigen receptor-T cell therapy for solid tumors require new clinical regimens. Expert Rev Anticancer Ther. 2017;17:1099-106.

12. Hariharan K, Braslawsky G, Black A, Raychaudhuri S, Hanna N. The induction of cytotoxic T cells and tumor regression by soluble antigen formulation. Cancer Res. 1995;55:3486-9.

13. Slingluff CL Jr. The present and future of peptide vaccines for cancer: single or multiple, long or short, alone or in combination? Cancer J. 2011;17:343-50.

14. Fadul CE, Fisher JL, Hampton TH, Lallana EC, Li Z, Gui J, et al. Immune response in patients with newly diagnosed glioblastoma multiforme treated with intranodal autologous tumor lysate-dendritic cell vaccination after radiation chemotherapy. J Immunother. 2011;34:382-9.

15. Porter DL, Levine BL, Kalos $\mathrm{M}$, Bagg A, June $\mathrm{CH}$. Chimeric antigen receptor-modified $\mathrm{T}$ cells in chronic lymphoid leukemia. N Engl J Med. 2011;365:725-33.

16. Hodi FS, O'Day SJ, McDermott DF, Weber RW, Sosman JA, Haanen JB, et al. Improved survival with ipilimumab in patients with metastatic melanoma. N Engl J Med. 2010;363:711-23.

17. Mellman I, Coukos G, Dranoff G. Cancer immunotherapy comes of age. Nature. 2011;480:480-9.

18. Robert C, Schachter J, Long GV, Arance A, Grob JJ, Mortier L, et al. Pembrolizumab versus ipilimumab in advanced melanoma. N Engl J Med. 2015;372:2521-32.

19. Borghaei H, Paz-Ares L, Horn L, Spigel DR, Steins M, Ready NE, et al. Nivolumab versus docetaxel in advanced nonsquamous non-small-cell lung cancer. N Engl J Med. 2015;373:1627-39.

20. Prasad V, Kaestner V. Nivolumab and pembrolizumab: monoclonal antibodies against programmed cell death-1 (PD-1) that are interchangeable. Semin Oncol. 2017;44:132-5.

21. Hoos A. Development of immuno-oncology drugs-from CTLA4 to PD1 to the next generations. Nat Rev Drug Discov. 2016;15:235-47.

22. Khalil DN, Smith EL, Brentjens RJ, Wolchok JD. The future of cancer treatment: immunomodulation, CARs and combination immunotherapy. Nat Rev Clin Oncol. 2016;13:273-90.

23. Palucka K, Banchereau J. Cancer immunotherapy via dendritic cells. Nat Rev Cancer. 2012;12:265-77.

24. Gajewski TF, Woo SR, Zha Y, Spaapen R, Zheng Y, Corrales L, et al. Cancer immunotherapy strategies based on overcoming barriers within the tumor microenvironment. Curr Opin Immunol. 2013;25:268-76.

25. Muller AJ, Scherle PA. Targeting the mechanisms of tumoral immune tolerance with small-molecule inhibitors. Nat Rev Cancer. 2006;6:613-25.

26. Peer D, Karp JM, Hong S, Farokhzad OC, Margalit R, Langer R. Nanocarriers as an emerging platform for cancer therapy. Nat Nanotechnol. 2007;2:751-60.

27. Mitragotri S, Anderson DG, Chen X, Chow EK, Ho D, Kabanov AV, et al. Accelerating the translation of nanomaterials in biomedicine. ACS Nano. 2015;9:6644-54.

28. Weissig V, Pettinger TK, Murdock N. Nanopharmaceuticals (part 1): products on the market. Int J Nanomedicine. 2014;9:4357-73.

29. Alexis F, Pridgen E, Molnar LK, Farokhzad OC. Factors affecting the clearance and biodistribution of polymeric nanoparticles. Mol Pharm. 2008;5:505-15.

30. Tang L, Yang X, Yin Q, Cai K, Wang H, Chaudhury I, et al. Investigating the optimal size of anticancer nanomedicine. Proc Natl Acad Sci U S A. 2014;111:15344-9.

31. Yu H, Tang Z, Zhang D, Song W, Zhang Y, Yang Y, et al. Pharmacokinetics, biodistribution and in vivo efficacy of cisplatin loaded poly (L-glutamic acid)-g-methoxy poly (ethylene glycol) complex nanoparticles for tumor therapy. J Control Release. 2015;205:89-97.

32. Elamanchili P, Diwan M, Cao M, Samuel J. Characterization of poly ( $D, L$-lactic-co-glycolic acid) based nanoparticulate system for enhanced delivery of antigens to dendritic cells. Vaccine. 2004;22:2406-12. 
33. Neumann S, Young K, Compton B, Anderson R, Painter G, Hook S. Synthetic TRP2 long-peptide and $\alpha$-galactosylceramide formulated into cationic liposomes elicit $\mathrm{CD}^{+} \mathrm{T}$-cell responses and prevent tumour progression. Vaccine. 2015;33:5838-44.

34. Larkin J, Chiarion-Sileni V, Gonzalez R, Grob JJ, Cowey CL, Lao CD, et al. Combined nivolumab and ipilimumab or monotherapy in untreated melanoma. N Engl J Med. 2015;373:23-34.

35. Jiang Y,Krishnan N, Zhou J, ChekuriS, WeiX, Kroll AV, etal.Engineered cell-membrane-coated nanoparticles directly present tumor antigens to promote anticancer immunity. Adv Mater. 2020;32:e2001808.

36. Ou W, Thapa RK, Jiang L, Soe ZC, Gautam M, Chang JH, et al. Regulatory T cell-targeted hybrid nanoparticles combined with immuno-checkpoint blockage for cancer immunotherapy. J Control Release. 2018;281:84-96.

37. Schuster M, Nechansky A, Kircheis R. Cancer immunotherapy. Biotechnol J. 2006;1:138-47.

38. Marincola FM, Jaffee EM, Hicklin DJ, Ferrone S. Escape of human solid tumors from T-cell recognition: Molecular mechanisms and functional significance. Adv Immunol. 2000;74:181-273.

39. Ochsenbein AF, Sierro S, Odermatt B, Pericin M, Karrer U, Hermans J, et al. Roles of tumour localization, second signals and cross priming in cytotoxic T-cell induction. Nature. 2001;411:1058-64.

40. Tamada K, Geng D, Sakoda Y, Bansal N, Srivastava R, Li Z, et al. Redirecting gene-modified T cells toward various cancer types using tagged antibodies. Clin Cancer Res. 2012;18:6436-45.

41. Schlimper C, Hombach AA, Abken H, Schmidt-Wolf IGH. Improved activation toward primary colorectal cancer cells by antigen-specific targeting autologous cytokine-induced killer cells. Clin Dev Immunol. 2012;2012:238924.

42. Morgan RA, Yang JC, Kitano M, Dudley ME, Laurencot CM, Rosenberg SA. Case report of a serious adverse event following the administration of $\mathrm{T}$ cells transduced with a chimeric antigen receptor recognizing ERBB2. Mol Ther. 2010;18:843-51.

43. Hege KM, Bergsland EK, Fisher GA, Nemunaitis JJ, Warren RS, McArthur JG, et al. Safety, tumor trafficking and immunogenicity of chimeric antigen receptor (CAR)-T cells specific for TAG-72 in colorectal cancer. J Immunother cancer. 2017;5:22.

44. Zhang C, Wang Z, Yang Z, Wang M, Li S, Li Y, et al. Phase I escalating-dose trial of CAR-T therapy targeting CEA+ metastatic colorectal cancers. Mol Ther. 2017;25:1248-58.

45. Thistlethwaite FC, Gilham DE, Guest RD, Rothwell DG, Pillai M, Burt DJ, et al. The clinical efficacy of firstgeneration carcinoembryonic antigen (CEACAM5)-specific CAR T cells is limited by poor persistence and transient pre-conditioning-dependent respiratory toxicity. Cancer Immunol Immunother. 2017;66:1425-36.

46. Li Y, Duo Y, Bao S, He L, Ling K, Luo J, et al. EpCAM aptamer-functionalized polydopamine-coated mesoporous silica nanoparticles loaded with DM1 for targeted therapy in colorectal cancer. Int J Nanomedicine. 2017;12:6239-57.

47. Zhang Q, Zhang H, Ding J, Liu H, Li H, Li H, et al. Combination therapy with EpCAM-CAR-NK-92 cells and regorafenib against human colorectal cancer models. J Immunol Res. 2018;2018:4263520.

48. Lee DW, Santomasso BD, Locke FL, Ghobadi A, Turtle CJ, Brudno JN, et al. ASTCT consensus grading for cytokine release syndrome and neurologic toxicity associated with immune effector cells. Biol Blood Marrow Transplant. 2019;25:625-38.

49. Davila ML, Riviere I, Wang X, Bartido S, Park J, Curran K, et al. Efficacy and toxicity management of 1928z CAR T cell therapy in B cell acute lymphoblastic leukemia. Sci Transl Med. 2014;6:224ra25.

50. Neelapu SS, Tummala S, Kebriaei P, Wierda W, Locke FL, Lin Y, et al. Toxicity management after chimeric antigen receptor T cell therapy: one size does not fit 'ALL'. Nat Rev Clin Oncol. 2018;15:218.

51. Lanier LL. Up on the tightrope: natural killer cell activation and inhibition. Nat Immunol. 2008;9:495-502.

52. Wu J, Lanier LL. Natural killer cells and cancer. Adv Cancer Res. 2003;90:127-56. 
53. López-Soto A, Gonzalez S, Smyth MJ, Galluzzi L. Control of metastasis by NK cells. Cancer Cell. 2017;32:135-54.

54. Souza-Fonseca-Guimaraes F, Cursons J, Huntington ND. The emergence of natural killer cells as a major target in cancer immunotherapy. Trends Immunol. 2019;40:142-58.

55. Burger MC, Zhang C, Harter PN, Romanski A, Strassheimer F, Senft C, et al. CAR-engineered NK cells for the treatment of glioblastoma: turning innate effectors into precision tools for cancer immunotherapy. Front Immunol. 2019;10:2683.

56. Morvan MG, Lanier LL. NK cells and cancer: you can teach innate cells new tricks. Nat Rev Cancer. 2016;16:7-19.

57. Ljunggren HG, Kärre K. In search of the 'missing self': MHC molecules and NK cell recognition. Immunol Today. 1990;11:237-44.

58. Brandstadter JD, Yang Y. Natural killer cell responses to viral infection. J Innate Immun. 2011;3:274-9.

59. Wehner R, Dietze K, Bachmann M, Schmitz M. The bidirectional crosstalk between human dendritic cells and natural killer cells. J Innate Immun. 2011;3:258-63.

60. Shibuya A, Campbell D, Hannum C, Yssel H, Franz-Bacon K, McClanahan T, et al. DNAM-1, a novel adhesion molecule involved in the cytolytic function of T lymphocytes. Immunity. 1996;4:573-81.

61. Huang R, Wang X, Zhou Y, Xiao Y. RANKL-induced M1 macrophages are involved in bone formation. Bone Res. 2017;5:17019.

62. Wang D, Lou J, Ouyang C, Chen W, Liu Y, Liu X, et al. Ras-related protein Rab10 facilitates TLR4 signaling by promoting replenishment of TLR4 onto the plasma membrane. Proc Natl Acad Sci. 2010;107:13806-11.

63. Zhang C, Oberoi P, Oelsner S, Waldmann A, Lindner A, Tonn T, et al. Chimeric antigen receptor-engineered NK-92 cells: an off-the-shelf cellular therapeutic for targeted elimination of cancer cells and induction of protective antitumor immunity. Front Immunol. 2017;8:533.

64. Walzer T, Dalod M, Robbins SH, Zitvogel L, Vivier E. Natural-killer cells and dendritic cells: "l'union fait la force." Blood. 2005;106:2252-8.

65. Fernandez NC, Lozier A, Flament C, Ricciardi-Castagnoli P, Bellet D, Suter M, et al. Dendritic cells directly trigger NK cell functions: cross-talk relevant in innate anti-tumor immune responses in vivo. Nat Med. 1999;5:405-11.

66. Veluchamy JP, Kok N, van der Vliet HJ, Verheul HMW, de Gruijl TD, Spanholtz J. The rise of allogeneic natural killer cells as a platform for cancer immunotherapy: recent innovations and future developments. Front Immunol. 2017;8:631.

67. Liu E, Tong Y, Dotti G, Shaim H, Savoldo B, Mukherjee M, et al. Cord blood NK cells engineered to express IL-15 and a CD19-targeted CAR show long-term persistence and potent antitumor activity. Leukemia. 2018;32:520-31.

68. Poilil Surendran S, Moon MJ, Park R, Jeong YY. Bioactive nanoparticles for cancer immunotherapy. Int J Mol Sci. 2018;19:3877.

69. Fan Y, Moon JJ. Nanoparticle drug delivery systems designed to improve cancer vaccines and immunotherapy. Vaccines. 2015;3:662-85.

70. Chithrani BD, Ghazani AA, Chan WCW. Determining the size and shape dependence of gold nanoparticle uptake into mammalian cells. Nano Lett. 2006;6:662-8.

71. Bramwell VW, Perrie Y. Particulate delivery systems for vaccines: what can we expect? J Pharm Pharmacol. 2006;58:717-28.

72. Yan W, Chen W, Huang L. Mechanism of adjuvant activity of cationic liposome: phosphorylation of a MAP kinase, ERK and induction of chemokines. Mol Immunol. 2007;44:3672-81.

73. Yan $\mathrm{W}$, Chen $\mathrm{W}$, Huang L. Reactive oxygen species play a central role in the activity of cationic liposome based cancer vaccine. J Control Release. 2008;130:22-8. 
74. Vangasseri DP, Cui Z, Chen W, Hokey DA, Falo LD Jr, Huang L. Immunostimulation of dendritic cells by cationic liposomes. Mol Membr Biol. 2006;23:385-95.

75. Kaur R, Bramwell VW, Kirby DJ, Perrie Y. Pegylation of DDA: TDB liposomal adjuvants reduces the vaccine depot effect and alters the Th1/Th2 immune responses. J Control release. 2012;158:72-7.

76. Tsai CC, Chang $\mathrm{CH}$, Chen LC, Chang YJ, Lan KL, Wu YH, et al. Biodistribution and pharmacokinetics of 188Re-liposomes and their comparative therapeutic efficacy with 5-fluorouracil in C26 colonic peritoneal carcinomatosis mice. Int J Nanomedicine. 2011;6:2607-19.

77. Nakamura T, Yamazaki D, Yamauchi J, Harashima H. The nanoparticulation by octaarginine-modified liposome improves $\alpha$-galactosylceramide-mediated antitumor therapy via systemic administration. J Control Release. 2013;171:216-24.

78. Patel JM, Vartabedian VF, Bozeman EN, Caoyonan BE, Srivatsan S, Pack CD, et al. Plasma membrane vesicles decorated with glycolipid-anchored antigens and adjuvants via protein transfer as an antigen delivery platform for inhibition of tumor growth. Biomaterials. 2016;74:231-44.

79. McHugh RS,NagarajanS,WangYC,SellKW,SelvarajP.Proteintransferofglycosyl-phosphatidylinositol-B7-1 into tumor cell membranes: a novel approach to tumor immunotherapy. Cancer Res. 1999;59:2433-7.

80. Molino NM, Neek M, Tucker JA, Nelson EL, Wang SW. Viral-mimicking protein nanoparticle vaccine for eliciting anti-tumor responses. Biomaterials. 2016;86:83-91.

81. Kushnir N, Streatfield SJ, Yusibov V. Virus-like particles as a highly efficient vaccine platform: diversity of targets and production systems and advances in clinical development. Vaccine. 2012;31:58-83.

82. Dewitte H, Van Lint S, Heirman C, Thielemans K, De Smedt SC, Breckpot K, et al. The potential of antigen and TriMix sonoporation using mRNA-loaded microbubbles for ultrasound-triggered cancer immunotherapy. J Control Release. 2014;194:28-36.

83. Bonehill A, Van Nuffel AMT, Corthals J, Tuyaerts S, Heirman C, François V, et al. Single-step antigen loading and activation of dendritic cells by mRNA electroporation for the purpose of therapeutic vaccination in melanoma patients. Clin Cancer Res. 2009;15:3366-75.

84. Shen L, Higuchi T, Tubbe I, Voltz N, Krummen M, Pektor S, et al. A trifunctional dextran-based nanovaccine targets and activates murine dendritic cells, and induces potent cellular and humoral immune responses in vivo. PLoS One. 2013;8:e80904.

85. Broaders KE, Cohen JA, Beaudette TT, Bachelder EM, Fréchet JMJ. Acetalated dextran is a chemically and biologically tunable material for particulate immunotherapy. Proc Natl Acad Sci. 2009;106:5497-502.

86. Zhang $\mathrm{D}, \mathrm{Wu} \mathrm{T}$, Qin $\mathrm{X}$, Qiao $\mathrm{Q}$ Shang $\mathrm{L}$, Song $\mathrm{Q}$, et al. Intracellularly generated immunological gold nanoparticles for combinatorial photothermal therapy and immunotherapy against tumor. Nano Lett. 2019;19:6635-46.

87. Cho NH, Cheong TC, Min JH, Wu JH, Lee SJ, Kim D, et al. A multifunctional core-shell nanoparticle for dendritic cell-based cancer immunotherapy. Nat Nanotechnol. 2011;6:675-82.

88. Ong C, Cha BG, Kim J. Mesoporous silica nanoparticles doped with gold nanoparticles for combined cancer immunotherapy and photothermal therapy. ACS Appl Bio Mater. 2019;2:3630-8.

89. Leleux J, Roy K. Micro and nanoparticle-based delivery systems for vaccine immunotherapy: an immunological and materials perspective. Adv Healthc Mater. 2013;2:72-94.

90. Zhang C, Shi G, Zhang J, Song H, Niu J, Shi S, et al. Targeted antigen delivery to dendritic cell via functionalized alginate nanoparticles for cancer immunotherapy. J Control Release. 2017;256:170-81.

91. Silva JM, Videira M, Gaspar R, Préat V, Florindo HF. Immune system targeting by biodegradable nanoparticles for cancer vaccines. J Control release. 2013;168:179-99.

92. Shao K, Singha S, Clemente-Casares X, Tsai S, Yang Y, Santamaria P. Nanoparticle-based immunotherapy for cancer. ACS Nano. 2015;9:16-30. 
93. Kasturi SP, Skountzou I, Albrecht RA, Koutsonanos D, Hua T, Nakaya HI, et al. Programming the magnitude and persistence of antibody responses with innate immunity. Nature. 2011;470:543-7.

94. Querec TD, Akondy RS, Lee EK, Cao W, Nakaya HI, Teuwen D, et al. Systems biology approach predicts immunogenicity of the yellow fever vaccine in humans. Nat Immunol. 2009;10:116-25.

95. Subbotin VM. Dendritic cell-based cancer immunotherapy: the stagnant approach and a theoretical solution. Drug Discov Today. 2014;19:834-7.

96. Scheicher C, Mehlig M, Dienes HP, Reske K. Uptake of bead-adsorbed versus soluble antigen by bone marrow derived dendritic cells triggers their activation and increases their antigen presentation capacity. Adv Exp Med Biol. 1995;378:253-5.

97. Nixon DF, Hioe C, Bian Z, Kuebler P, Li ML, Qiu H, et al. Synthetic peptides entrapped in microparticles can elicit cytotoxic T cell activity. Vaccine. 1996;14:1523-30.

98. Diwan M, Elamanchili P, Lane H, Gainer A, Samuel J. Biodegradable nanoparticle mediated antigen delivery to human cord blood derived dendritic cells for induction of primary T cell responses. J Drug Target. 2003;11:495-507.

99. Thiele L, Rothen-Rutishauser B, Jilek S, Wunderli-Allenspach H, Merkle HP, Walter E. Evaluation of particle uptake in human blood monocyte-derived cells in vitro. Does phagocytosis activity of dendritic cells measure up with macrophages? J Control Release. 2001;76:59-71.

100. Slamon DJ, Godolphin W, Jones LA, Holt JA, Wong SG, Keith DE, et al. Studies of the HER-2/neu protooncogene in human breast and ovarian cancer. Science. 1989;244:707-12.

101. Disis ML, Gooley TA, Rinn K, Davis D, Piepkorn M, Cheever MA, et al. Generation of T-cell immunity to the HER-2/neu protein after active immunization with HER-2/neu peptide-based vaccines. J Clin Oncol. 2002;20:2624-32.

102. Slamon DJ, Leyland-Jones B, Shak S, Fuchs H, Paton V, Bajamonde A, et al. Use of chemotherapy plus a monoclonal antibody against HER2 for metastatic breast cancer that overexpresses HER2. N Engl J Med. 2001;344:783-92.

103. Wei H, Wang S, Zhang D, Hou S, Qian W, Li B, et al. Targeted delivery of tumor antigens to activated dendritic cells via CD11c molecules induces potent antitumor immunity in mice. Clin Cancer Res. 2009;15:4612-21.

104. Shukla S, Myers JT, Woods SE, Gong X, Czapar AE, Commandeur U, et al. Plant viral nanoparticlesbased HER2 vaccine: Immune response influenced by differential transport, localization and cellular interactions of particulate carriers. Biomaterials. 2017;121:15-27.

105. Khaldoyanidi SK, Glinsky VV, Sikora L, Glinskii AB, Mossine VV, Quinn TP, et al. MDA-MB-435 human breast carcinoma cell homo-and heterotypic adhesion under flow conditions is mediated in part by Thomsen-Friedenreich antigen-galectin-3 interactions. J Biol Chem. 2003;278:4127-34.

106. Rao L, Yu G, Meng Q, Bu L, Tian R, Lin L, et al. Cancer cell membrane-coated nanoparticles for personalized therapy in patient-derived xenograft models. Adv Funct Mater. 2019;29:1905671.

107. Fang RH, Kroll A V, Gao W, Zhang L. Cell membrane coating nanotechnology. Adv Mater. 2018;30:e1706759.

108. Zhang Q Dehaini D, Zhang Y, Zhou J, Chen X, Zhang L, et al. Neutrophil membrane-coated nanoparticles inhibit synovial inflammation and alleviate joint damage in inflammatory arthritis. Nat Nanotechnol. 2018;13:1182-90.

109. Hu CMJ, Fang RH, Wang KC, Luk BT, Thamphiwatana S, Dehaini D, et al. Nanoparticle biointerfacing by platelet membrane cloaking. Nature. 2015;526:118-21.

110. Parodi A, Quattrocchi N, Van De Ven AL, Chiappini C, Evangelopoulos M, Martinez JO, et al. Synthetic nanoparticles functionalized with biomimetic leukocyte membranes possess cell-like functions. Nat Nanotechnol. 2013;8:61-8.

111. Hu CMJ, Zhang L, Aryal S, Cheung C, Fang RH, Zhang L. Erythrocyte membrane-camouflaged polymeric nanoparticles as a biomimetic delivery platform. Proc Natl Acad Sci. 2011;108:109805. 
112. Schwartzentruber DJ, Lawson DH, Richards JM, Conry RM, Miller DM, Treisman J, et al. gp100 peptide vaccine and interleukin-2 in patients with advanced melanoma. N Engl J Med. 2011;364:2119-27.

113. Hamdy S, Molavi O, Ma Z, Haddadi A, Alshamsan A, Gobti Z, et al. Co-delivery of cancer-associated antigen and Toll-like receptor 4 ligand in PLGA nanoparticles induces potent CD8+ T cell-mediated anti-tumor immunity. Vaccine. 2008;26:5046-57.

114. Xu Z, Ramishetti S, Tseng YC, Guo S, Wang Y, Huang L. Multifunctional nanoparticles co-delivering Trp2 peptide and $\mathrm{CpG}$ adjuvant induce potent cytotoxic T-lymphocyte response against melanoma and its lung metastasis. J Control Release. 2013;172:259-65.

115. Deng G, Sun Z, Li S, Peng X, Li W, Zhou L, et al. Cell-membrane immunotherapy based on natural killer cell membrane coated nanoparticles for the effective inhibition of primary and abscopal tumor growth. ACS Nano. 2018;12:12096-108.

116. Yang R, Xu J, Xu L, Sun X, Chen Q, Zhao Y, et al. Cancer cell membrane-coated adjuvant nanoparticles with mannose modification for effective anticancer vaccination. ACS Nano. 2018;12:5121-9.

117. Turtle CJ, Riddell SR. Artificial antigen presenting cells for use in adoptive immunotherapy. Cancer J. 2010;16:374-81.

118. Eggermont LJ, Paulis LE, Tel J, Figdor CG. Towards efficient cancer immunotherapy: advances in developing artificial antigen-presenting cells. Trends Biotechnol. 2014;32:456-65.

119. Fang RH, Zhang L. Nanoparticle-based modulation of the immune system. Annu Rev Chem Biomol Eng. 2016;7:305-26.

120. Gorbet MJ, Ranjan A. Cancer immunotherapy with immunoadjuvants, nanoparticles, and checkpoint inhibitors: recent progress and challenges in treatment and tracking response to immunotherapy. Pharmacol Ther. 2020;207:107456.

121. Long G V, Atkinson V, Cebon JS, Jameson MB, Fitzharris BM, McNeil CM, et al. Standard-dose pembrolizumab in combination with reduced-dose ipilimumab for patients with advanced melanoma (KEYNOTE-029): an open-label, phase 1b trial. Lancet Oncol. 2017;18:1202-10.

122. Deeks ED. Pembrolizumab: a review in advanced melanoma. Drugs. 2016;76:375-86.

123. Overman MJ, McDermott R, Leach JL, Lonardi S, Lenz HJ, Morse MA, et al. Nivolumab in patients with metastatic DNA mismatch repair-deficient or microsatellite instability-high colorectal cancer (CheckMate 142): an open-label, multicentre, phase 2 study. Lancet Oncol. 2017;18:1182-91.

124. Luo W, Wang Z, Tian P, Li W. Safety and tolerability of PD-1/PD-L1 inhibitors in the treatment of non-small cell lung cancer: a meta-analysis of randomized controlled trials. J Cancer Res Clin Oncol. 2018;144:1851-9.

125. Brower V. Anti-PD-L1 inhibitor durvalumab in bladder cancer. Lancet Oncol. 2016;17:e275.

126. Zheng P, Zhou Z. Human cancer immunotherapy with PD-1/PD-L1 blockade. Biomark Cancer. 2015;7 Suppl 2:15-8.

127. Hargadon KM, Johnson CE, Williams CJ. Immune checkpoint blockade therapy for cancer: an overview of FDA-approved immune checkpoint inhibitors. Int Immunopharmacol. 2018;62:29-39.

128. Chen Q, Xu L, Liang C, Wang C, Peng R, Liu Z. Photothermal therapy with immune-adjuvant nanoparticles together with checkpoint blockade for effective cancer immunotherapy. Nat Commun. 2016;7:13193.

129. Traini G, Ruiz-de-Angulo A, Blanco-Canosa JB, Zamacola Bascarán K, Molinaro A, Silipo A, et al. Cancer Immunotherapy of TLR4 agonist-antigen constructs enhanced with pathogen-mimicking magnetite nanoparticles and checkpoint blockade of PD-L1. Small. 2019;15:e1803993.

130. van der Zanden SY, Luimstra JJ, Neefjes J, Borst J, Ovaa H. Opportunities for small molecules in cancer immunotherapy. Trends Immunol. 2020;41:493-511.

131. Smith M, García-Martínez E, Pitter MR, Fucikova J, Spisek R, Zitvogel L, et al. Trial watch: Toll-like receptor agonists in cancer immunotherapy. Oncoimmunology. 2018;7:e1526250. 
132. Guzik K, Zak KM, Grudnik P, Magiera K, Musielak B, Törner R, et al. Small-molecule inhibitors of the programmed cell death-1/programmed death-ligand 1 (PD-1/PD-L1) interaction via transiently induced protein states and dimerization of PD-L1. J Med Chem. 2017;60:5857-67.

133. Ganesan A, Ahmed M, Okoye I, Arutyunova E, Babu D, Turnbull WL, et al. Comprehensive in vitro characterization of PD-L1 small molecule inhibitors. Sci Rep. 2019;9:1-19.

134. Li SD, Huang L. Pharmacokinetics and biodistribution of nanoparticles. Mol Pharm. 2008;5:496-504.

135. Hashida M, Opanasopit P, Nishikawa M. Factors affecting drug and gene delivery: effects of interaction with blood components. Crit Rev Ther Drug Carr Syst. 2002;19:191-233.

136. Dobrovolskaia MA, McNeil SE. Immunological properties of engineered nanomaterials. Nat Nanotechnol. 2007;2:469-78.

137. Boraschi D, Costantino L, Italiani P. Interaction of nanoparticles with immunocompetent cells: nanosafety considerations. Nanomedicine. 2012;7:121-31.

138. Shi Y, Evans JE, Rock KL. Molecular identification of a danger signal that alerts the immune system to dying cells. Nature. 2003;425:516-21.

139. Maynard AD, Warheit DB, Philbert MA. The new toxicology of sophisticated materials: nanotoxicology and beyond. Toxicol Sci. 2011;120 Suppl 1:S109-29.

140. Hegde PS, Chen DS. Top 10 challenges in cancer immunotherapy. Immunity. 2020;52:17-35.

141. Freeman GJ, Long AJ, Iwai Y, Bourque K, Chernova T, Nishimura H, et al. Engagement of the PD-1 immunoinhibitory receptor by a novel B7 family member leads to negative regulation of lymphocyte activation. J Exp Med. 2000;192:1027-34.

142. Dong Y, Sun Q, Zhang X. PD-1 and its ligands are important immune checkpoints in cancer. Oncotarget. 2017;8:2171-86.

143. Ebert PJR, Cheung J, Yang Y, McNamara E, Hong R, Moskalenko M, et al. MAP kinase inhibition promotes T cell and anti-tumor activity in combination with PD-L1 checkpoint blockade. Immunity. 2016;44:609-21.

144. Shrimali RK, Ahmad S, Verma V, Zeng P, Ananth S, Gaur P, et al. Concurrent PD-1 blockade negates the effects of OX40 agonist antibody in combination immunotherapy through inducing T-cell apoptosis. Cancer Immunol Res. 2017;5:755-66.

145. Dranoff G. Experimental mouse tumour models: what can be learnt about human cancer immunology? Nat Rev Immunol. 2012;12:61-6.

146. Gould SE, Junttila MR, de Sauvage FJ. Translational value of mouse models in oncology drug development. Nat Med. 2015;21:431-9.

147. Maude SL, Frey N, Shaw PA, Aplenc R, Barrett DM, Bunin NJ, et al. Chimeric antigen receptor T cells for sustained remissions in leukemia. N Engl J Med. 2014;371:1507-17.

148. Gettinger SN, Horn L, Gandhi L, Spigel DR, Antonia SJ, Rizvi NA, et al. Overall survival and long-term safety of nivolumab (anti-programmed death 1 antibody, BMS-936558, ONO-4538) in patients with previously treated advanced non-small-cell lung cancer. J Clin Oncol. 2015;33:2004-12.

149. Irvine DJ, Dane EL. Enhancing cancer immunotherapy with nanomedicine. Nat Rev Immunol. 2020;5:321-34.

150. Shen CJ, Jameson KL, Weiss J, Hackman T, Dixon R, Akulian JA, et al. NANORAY-1100: a phase I study of NBTXR3 activated by radiotherapy in patients with advanced cancers treated with anti-PD-1 therapy. J Clin Oncol. 2020;38 Suppl 5:TPS86.

151. Kyte JA, Andresen NK, Russnes HG, Fretland Sø, Falk RS, Lingjærde OC, et al. ICON: a randomized phase IIb study evaluating immunogenic chemotherapy combined with ipilimumab and nivolumab in patients with metastatic hormone receptor positive breast cancer. J Transl Med. 2020;18:269.

152. Kantoff PW, Higano CS, Shore ND, Berger ER, Small EJ, Penson DF, et al. Sipuleucel-T immunotherapy for castration-resistant prostate cancer. N Engl J Med. 2010;363:411-22. 
153. Liu L, Zong ZM, Liu Q Jiang SS, Zhang Q, Cen LQ et al. A novel galactose-PEG-conjugated biodegradable copolymer is an efficient gene delivery vector for immunotherapy of hepatocellular carcinoma. Biomaterials. 2018;184:20-30.

154. Jeanbart L, Kourtis IC, Van Der Vlies AJ, Swartz MA, Hubbell JA. 6-Thioguanine-loaded polymeric micelles deplete myeloid-derived suppressor cells and enhance the efficacy of T cell immunotherapy in tumorbearing mice. Cancer Immunol Immunother. 2015;64:1033-46.

155. Yim H, Park W, Kim D, Fahmy TM, Na K. A self-assembled polymeric micellar immunomodulator for cancer treatment based on cationic amphiphilic polymers. Biomaterials. 2014;35:9912-9.

156. Garg SM, Vakili MR, Molavi O, Lavasanifar A. Self-Associating Poly (ethylene oxide)-block-poly ( $\alpha$-carboxyl$\varepsilon$-caprolactone) drug conjugates for the delivery of STAT3 inhibitor JSI-124: potential application in cancer immunotherapy. Mol Pharm. 2017;14:2570-84.

157. Perica K, Tu A, Richter A, Bieler JG, Edidin M, Schneck JP. Magnetic field-induced T cell receptor clustering by nanoparticles enhances $\mathrm{T}$ cell activation and stimulates antitumor activity. ACS Nano. 2014;8:2252-60.

158. Lu K, He C, Guo N, Chan C, Ni K, Weichselbaum RR, et al. Chlorin-based nanoscale metal-organic framework systemically rejects colorectal cancers via synergistic photodynamic therapy and checkpoint blockade immunotherapy. J Am Chem Soc. 2016;138:12502-10.

159. Luo Z, Wang C, Yi H, Li P, Pan H, Liu L, et al. Nanovaccine loaded with poly I:C and STAT3 siRNA robustly elicits anti-tumor immune responses through modulating tumor-associated dendritic cells in vivo. Biomaterials. 2015;38:50-60.

160. Kwong B, Liu H, Irvine DJ. Induction of potent anti-tumor responses while eliminating systemic side effects via liposome-anchored combinatorial immunotherapy. Biomaterials. 2011;32:5134-47.

161. Wang C, Zhuang Y, Zhang Y, Luo Z, Gao N, Li P, et al. Toll-like receptor 3 agonist complexed with cationic liposome augments vaccine-elicited antitumor immunity by enhancing TLR3-IRF3 signaling and type I interferons in dendritic cells. Vaccine. 2012;30:4790-9.

162. Van Broekhoven CL, Parish CR, Demangel C, Britton WJ, Altin JG. Targeting dendritic cells with antigencontaining liposomes: a highly effective procedure for induction of antitumor immunity and for tumor immunotherapy. Cancer Res. 2004;64:4357-65.

163. Wu C, Guan X, Xu J, Zhang Y, Liu Q, Tian Y, et al. Highly efficient cascading synergy of cancer photoimmunotherapy enabled by engineered graphene quantum dots/photosensitizer/CpG oligonucleotides hybrid nanotheranostics. Biomaterials. 2019;205:106-19.

164. Guo L, Yan DD, Yang D, Li Y, Wang X, Zalewski O, et al. Combinatorial photothermal and immuno cancer therapy using chitosan-coated hollow copper sulfide nanoparticles. ACS Nano. 2014;8:5670-81.

165. Marrache S, Choi JH, Tundup S, Zaver D, Harn DA, Dhar S. Immune stimulating photoactive hybrid nanoparticles for metastatic breast cancer. Integr Biol. 2013;5:215-23.

166. Mejías R, Pérez-Yagüe S, Gutiérrez L, Cabrera LI, Spada R, Acedo P, et al. Dimercaptosuccinic acidcoated magnetite nanoparticles for magnetically guided in vivo delivery of interferon gamma for cancer immunotherapy. Biomaterials. 2011;32:2938-52.

167. Jang B, Xu L, Moorthy MS, Zhang W, Zeng L, Kang M, et al. Lipopolysaccharide-coated CuS nanoparticles promoted anti-cancer and anti-metastatic effect by immuno-photothermal therapy. Oncotarget. 2017;8:105584-95.

168. Cano-Mejia J, Burga RA, Sweeney EE, Fisher JP, Bollard CM, Sandler AD, et al. Prussian blue nanoparticlebased photothermal therapy combined with checkpoint inhibition for photothermal immunotherapy of neuroblastoma. Nanomedicine Nanotechnology, Biol Med. 2017;13:771-81.

169. Yu X, Gao D, Gao L, Lai J, Zhang C, Zhao Y, et al. Inhibiting metastasis and preventing tumor relapse by triggering host immunity with tumor-targeted photodynamic therapy using photosensitizer-loaded functional nanographenes. ACS Nano. 2017;11:10147-58. 
170. Duan X, Chan C, Guo N, Han W, Weichselbaum RR, Lin W. Photodynamic therapy mediated by nontoxic core-shell nanoparticles synergizes with immune checkpoint blockade to elicit antitumor immunity and antimetastatic effect on breast cancer. J Am Chem Soc. 2016;138:16686-95.

171. Harini L, Srivastava S, Gnanakumar GP, Karthikeyan B, Ross C, Krishnakumar V, et al. An ingenious non-spherical mesoporous silica nanoparticle cargo with curcumin induces mitochondria-mediated apoptosis in breast cancer (MCF-7) cells. Oncotarget. 2019;10:1193-208.

172. Ma W, Zhu D, Li J, Chen X, Xie W, Jiang X, et al. Coating biomimetic nanoparticles with chimeric antigen receptor $\mathrm{T}$ cell-membrane provides high specificity for hepatocellular carcinoma photothermal therapy treatment. Theranostics. 2020;10:1281-95.

173. Xu J, Xu L, Wang C, Yang R, Zhuang Q, Han X, et al. Near-infrared-triggered photodynamic therapy with multitasking upconversion nanoparticles in combination with checkpoint blockade for immunotherapy of colorectal cancer. ACS Nano. 2017;11:4463-74. 